Universidade de Brasília

Instituto de Ciência Política e Relações Internacionais

Departamento de Relações Internacionais

\title{
A Associação Brasileira de Organizações Não- Governamentais e sua ação de caráter internacional
}

\author{
Mariana Branco Pereira
}

Monografia apresentada ao Departamento de Relações Internacionais da Universidade de Brasília como requisito para obtenção do grau de especialista em Relações Internacionais, sob a orientação da professora Cristina Yumie Aoki Inoue

Brasília, 2008 


\section{Resumo}

Este trabalho busca lançar uma luz sobre como se dá a atuação de caráter internacional da Associação Brasileira de Organizações Não-Governamentais (ABONG), em face de fenômenos recentes como a globalização, a proliferação de atores não-estatais na cena internacional, a constituição de um quadro de governança global e a emergência de uma sociedade civil global. A ABONG é, ao mesmo tempo, uma entidade não-governamental e uma organização representativa de muitas entidades não-governamentais brasileiras. Surgiu em 1991, em meio a um cenário de mudanças e reestruturações - globalização, fim da Guerra Fria, novos atores e agendas ganhando espaço na cena internacional - e teve, como um de seus objetivos à época do surgimento, a união de entidades da sociedade civil com propósitos semelhantes aos seus para fazer face à nova realidade. Assim, a ABONG é uma Organização NãoGovernamental de atuação primordialmente nacional, com fortes raízes e interesses a serem realizados no Brasil. Também representa entidades que têm, em sua maioria, uma atuação nacional, regional ou local. Mas, até mesmo dado o seu papel representativo, não pode ignorar a cena internacional e não a ignora. Queremos compreender, através da análise da atuação com cunho internacional da ABONG por um período de tempo, de que forma a Associação se articula para realizar seus interesses neste complexo cenário global hoje existente e que tipos de ação com algum cunho internacional impetra para isso. Paralelamente à análise do trabalho da ABONG, vamos discorrer e trazer algumas informações sobre mecanismos de participação das ONGs no cenário internacional, história do surgimento dessas entidades, personalidade jurídica, etc.

\footnotetext{
PALAVRAS-CHAVE: ORGANIZAÇÕES NÃO-GOVERNAMENTAIS, SOCIEDADE CIVIL, SOCIEDADE CIVIL GLOBAL
} 


\section{SUMÁRIO}

INTRODUÇÃO

Algumas considerações teóricas $\quad 9$

1 - Sociedade civil e a evolução do conceito $\quad 9$

2 - Sociedade civil global $\quad 13$

3 - Sobre as ONGs 16

4 - Redes e cooperação 17

$\begin{array}{lr}\text { Metodologia } & 20\end{array}$

Capítulo I - ONGs: história, personalidade jurídica, mecanismos de atuação junto à ONU, marco legal no Brasil e o surgimento da ABONG 22

1 - ONGs: breve histórico no mundo e no Brasil 23

2 - Personalidade jurídica das ONGs 25

3 - Mecanismos de atuação junto à ONU 26

4 - Marco legal das ONGs no Brasil 29

5 - Quem é a ABONG: surgimento e características 32

Análise dos relatórios da Associação Brasileira de Organizações NãoGovernamentais

Breve explicação dos critérios que nortearam nossa análise 38

Capítulo II - As parcerias e articulações da ABONG com atores internacionais e seus objetivos $\quad 43$

1 - Parcerias para fortalecimento institucional 44

2 - Parcerias ligadas a outras metas 48

2.1 - Parcerias que têm relação com o fortalecimento da sociedade civil 49

2.2 - Parcerias ligadas a objetivos finalitários $\quad 52$

Encerrando: um breve balanço das parcerias $\quad 55$

Capítulo III - As outras formas de atuação internacional da ABONG e o peso da ação internacional face à nacional

1 - A organização ou participação da ABONG em eventos do tipo encontro para discussão e diálogo 58

2 - Acompanhamento e posicionamento com relação a temas da agenda internacional ou ligados ao cenário global 62 3 - O monitoramento do cumprimento de tratados internacionais, denúncia de descumprimento dos mesmos ou de violação de direitos, e a coleta de informações locais para divulgação internacional

Breve balanço das outras formas de atuação internacional, em comparação com as parcerias

4 - O peso da ação de caráter internacional face à ação estritamente nacional 72

Conclusões 
Anexos 


\section{Introdução}

Já há algum tempo os Estados-nação deixaram de ser os únicos players do cenário internacional. A partir da II Guerra Mundial, atores não-estatais têm crescido em número e ganhado uma influência que vai além das fronteiras de seus países de origem. De interestatais que eram, com foco majoritariamente na segurança de Estado e no interesse nacional, as relações internacionais passaram a um estágio mais complexo. O fenômeno da globalização - com liberalização econômica, avanço nas tecnologias de comunicação e transportes, quebra das fronteiras culturais e políticas trouxe, por sua própria natureza, atores os mais diversos para compartilhar a arena internacional com os Estados. As chamadas Organizações Não-Governamentais (ONGs), empresas transnacionais, associações de todo tipo estão entre eles.

Temos que lembrar, ainda, que houve uma proliferação não apenas de atores não-estatais, mas dos próprios Estados soberanos. No século XIX eram algumas dezenas, enquanto que hoje chegam à casa das centenas. Esses estados, vale lembrar, organizaram-se em Organizações Internacionais (OIs) que os representam. Ou seja, mais atores e mais fragmentação. Um sistema ainda mais complexo.

Smouts (2004:129) comenta a transformação sofrida pela sociedade internacional em um período curto de tempo: em menos de meio século, diz a autora, ela passou do modelo de uma comunidade de Estados com objetivos egoístas, com foco no poder e no interesse nacional, para o de uma sociedade além-fronteiras “heterogênica, multicêntrica, em busca de espaço público e regulação”. É nesse âmbito que a sociedade internacional se torna complexa, e que os atores passam a apresentar-se em maior número e com características mais diversas.

Dentre esses atores variados existentes hoje, decidimos tratar neste trabalho das chamadas ONGs por motivos vários. São atores interessantes no que diz respeito à cena internacional, porque são em grande número - têm crescido incontestavelmente em quantidade nas últimas décadas - e vêem conseguindo alcançar resultados no que diz respeito à articulação e peso de suas ações. Ao mesmo tempo, no entanto, em que conseguem obter resultados, as ONGs têm sua atuação limitada e cerceada por uma série de questões: carecem de personalidade jurídica internacional, e, por isso, são apenas as observadoras e as consultoras do cenário de regulação global. Estão submetidas às legislações de seus Estados de origem e neles são sujeitos de direito, ao contrário do que ocorre além das fronteiras nacionais. Tal contradição, por si só, torna já 
as ONGs interessantes, e é mais interessante ainda o fato de, ainda cerceadas e com ação limitada, elas se aventurarem na cena global, dela tomarem conta e nela obterem resultados.

As ONGs são atores dignos de atenção, também, por serem parte importante quiçá o maior expoente - deste fenômeno do nosso século e final do século passado da emergência de um grupo que se denomina uma sociedade civil com características bem específicas, como veremos mais à frente em nossas considerações teóricas. O fenômeno, os atores, os conceitos nele envolvidos são difusos ainda, pouco delimitados e envolvidos em uma grande nebulosa. Trata-se de um fenômeno muito jovem, e, portanto, será preciso tempo para vermos no que vai desembocar e para que haja mais justeza conceitual acerca dele. Entretanto, nos interessou delinear um pouco, neste trabalho, toda o emaranhado teórico a cercar hoje as ONGs e o contexto no qual estão inseridas: dúvidas, reestruturações conceituais, concordâncias, discordâncias. Essas são algumas das questões que nos levaram a focar-nos nas Organizações NãoGovernamentais neste estudo.

Á luz de todo esse contexto, escolhemos analisar a atuação neste cenário internacional complexo por parte da Associação Brasileira de ONGs, a ABONG. Representante de algumas entidades não-governamentais brasileiras que têm os seus mesmos princípios e objetivos, e ao mesmo tempo ela mesma uma entidade nãogovernamental, a ABONG tem importância histórica no que toca à trajetória das ONGs no Brasil: surge com o intuito de representar um determinado grupo de movimentos sociais, e uma de suas missões é justamente a organização das entidades para fazer face à reestruturação sofrida pelo mundo e aos desafios por ela trazidos ${ }^{1}$. Por seu próprio papel de representante de organizações e em razão de seus princípios e objetivos muitos deles tendo ligações com temas passíveis de extrapolar o nacional e entrar na agenda global - a Associação não pode ignorar a cena internacional. A nossa curiosidade, neste trabalho, foi saber como a ABONG se move e cumpre seu papel de entidade representativa e perseguidora de uma série de objetivos em um mundo de relações internacionais altamente complexas e de fronteiras cada vez mais tênues. Queríamos saber quais as suas principais atividades com algum foco internacional e quais os principais interesses por trás delas.

\footnotetext{
${ }^{1}$ Cf. História, disponível em www.abong.org.br, acesso em 10 de janeiro de 2008.
} 
A ABONG é bastante lembrada como representante oficial da sociedade civil brasileira - embora não represente todas as entidades não-governamentais nacionais, como veremos mais adiante neste trabalho. Seu banco de dados, com informações sobre suas filiadas, é constantemente consultado quando se quer ter uma idéia do perfil de ONGs brasileiras, quais os temas com que trabalham, entre outras coisas.

Entretanto, parece-nos que é pouco lembrada a atuação da ABONG enquanto ela própria, em favor das suas plataformas, valores, princípios e, claro, em favor das entidades que representa. E o fato é que ela tem, sim, uma atuação própria, e sua atividade não fica restrita ao âmbito estritamente nacional. A Asssociação Brasileira de ONGs é uma das articuladoras do Fórum Social Mundial, por exemplo, um evento hoje transnacionalizado e centro de encontro e discussões de organizações e personagens que desejam fazer um contraponto à atual ordem global vigente, em especial no que toca ao sistema econômico. Participa ainda, como firmadora, de vários outros convênios e parcerias internacionais, o que é possível detectar mesmo em uma consulta superficial à sua página na Internet.

Acreditamos, a partir daí, que seria útil traçar um pequeno perfil de como funciona essa ação internacional, do que significam tais parcerias e iniciativas como o Fórum, além de detectar em que outras formas de atuação com algum cunho internacional a ABONG se envolve, dado o papel importante que tem a Associação no Brasil. A entidade recorre a mecanismos formais de atuação do sistema internacional? Com que interesses firma parcerias, quais as características delas? Qual a relação da ABONG com as OIs? Ela faz denúncias, monitora casos de desrespeito e violação aos direitos humanos, ou fornece dados sobre outros assuntos a instâncias internacionais regulatórias? Veremos a resposta para essas questões ao longo do trabalho.

Paralelamente a traçar um pequeno panorama da ação de caráter internacional da ABONG e de suas finalidades, buscamos também, nesta pesquisa, lançar um pouco de luz sobre este complexo tema das ONGs em geral, e sua presença em um mundo cada vez mais globalizado e interdependente.

Na próxima seção deste trabalho, faremos algumas considerações teóricas e uma tentativa de delineação conceitual acerca de termos e idéias pertinentes ao universo de nosso estudo - sociedade civil, sociedade civil global, ONGs. Em seguida, após as páginas dedicadas aos marcos teóricos e à conceituação, vamos falar da metodologia utilizada por nós para análise das ações de caráter internacional da Associação Brasileira de ONGs. Tudo isso compõe a parte introdutória desta pesquisa. 
Concluídas essas considerações iniciais, nosso trabalho vai dividir-se em três capítulos. No primeiro, trataremos da história das ONGs no mundo e no Brasil, da situação dessas entidades do ponto de vista legal, dos mecanismos de participação para essas atores disponíveis junto ás Nações Unidas e, por fim, do histórico e características da ABONG. Os capítulos II e III, por sua vez, serão dedicados à análise da atividade internacional da Associação Brasileira de ONGs, e a nossa fonte serão os relatórios da entidade. Antes de passar ao segundo e ao terceiro capítulos, entretanto, faremos uma breve exposição dos critérios que nortearam a análise dos dados contidos nos documentos, e sobre como essa análise foi estruturada. Essa exposição será mais detalhada do que aquela disponível na seção deste trabalho dedicada à metodologia de pesquisa. Ela tem o objetivo de ser funcional, facilitando a leitura e compreensão das páginas em que é feita a análise dos relatórios.

Terminada a análise, passaremos às considerações finais deste estudo, e tentaremos chegar a algumas conclusões sobre a ação internacional da ABONG. Para isso, usaremos como base a literatura disponível sobre o tema das ONGs e sociedade civil, aquilo que foi encontrado na análise documental, e, ainda, entrevistas com representantes da Associação Brasileira de ONGs. 


\section{Algumas considerações teóricas \\ 1 - Sociedade civil e a evolução do conceito}

O nosso trabalho baseia-se no pressuposto de que existe, nos dias de hoje, uma sociedade civil global. Antes que tratemos dela, no entanto, é importante destacar que, abaixo do âmbito global, temos uma sociedade civil doméstica, e que a sociedade civil local existiu antes da global.

Wapner (1997:67-68) destaca que o conceito de sociedade civil tem uma história longa, "almost wholly confined to reflection on domestic collective life". Entretanto, ainda segundo o autor, "to understand the meaning of civil society at the global level, it is useful to appreciate, at least in broad outline, some of the more important developments in the evolution of the concept's relevance at the domestic level”.

É o que faremos a seguir, a título de contextualização. Afinal, o termo sociedade civil tem uma carga conceitual densa e antiga, que em muitos momentos o afasta da conotação que ele ganhou hoje. Ao mesmo tempo, seguir a evolução do conceito é importante para compreender o significado mais aceito atualmente, significado este que o aproxima das ONGs, nosso objeto de estudo.

O uso da expressão sociedade civil remete à Grécia Antiga. A expressão grega politik koinonia (comunidade política ou sociedade política), utilizada por Aristóteles, pode ser traduzida para o latim societas civilis (Cohen e Arato,1997:4 apud Saraiva, 2003:18). A concepção clássica do termo era de que Estado e sociedade civil eram a mesma coisa. A esfera privada (a casa, o lar, as questões pessoais) não era separada da esfera pública, porque simplesmente não poderia existir por conta própria, de forma dissociada. Os cidadãos eram também governantes, e a sociedade civil era fundada sobre o conceito de homem político, que quer o bem público.

Wapner (1997:68) ressalta que é importante para as conceituações mais recentes de sociedade civil o fato de, dentro da concepção clássica, os homens se guiarem por um conjunto de normas e valores (ethos) que iam além das regras formais e estatais. Como coloca o autor, na situação que então existia, "governance was not simply a matter of governmental statutes”.

A concepção cristã de sociedade civil, vigente na Idade Média, já tem um caráter diverso. Se na visão clássica o termo é indissociável da vida política - intrinsecamente 
ligada à esfera doméstica - no período medieval temos um entendimento das realizações e aspirações políticas como pertencentes à esfera mundana, e mais próximas do "mal" do que do "bem” (para os gregos, a participação política estava ligada à idéia de contribuição para o bem público). Assim, a coesão social da época se dá em torno do cristianismo: passa a existir uma Christian Commonweath (Comunidade Cristã), congregando Igreja, Estado e associações civis (Saraiva, 2003: 23). A Igreja está no centro da organização, e tomou o lugar da política como esfera das aspirações morais mais elevadas. Entretanto, sociedade civil, aqui, ainda não aparece de forma separada do Estado - como acontece na concepção vigente hoje.

A idéia da Igreja como centro fundamental em torno do qual se movimentava a sociedade política e doméstica só é definitivamente abandonada com a Reforma Protestante - que critica qualquer ingerência da Igreja nos assuntos mundanos - e com o pensamento de Maquiavel, no século XVI. Saraiva (Ibid:25) cita a mais conhecida obra do filósofo, O Príncipe (1513), como importante por marcar a separação entre poder secular e religioso, e também porque, nela, o autor defende a necessidade de um Estado centralizador e unitário. Entretanto, ninguém trata ainda de uma distinção clara entre sociedade civil e Estado.

Além disso, um componente que será importante no futuro para outros autores, ainda permanece à parte das análises citadas a respeito da vida política e em sociedade: o mercado. Saraiva (Ibid:20) destaca que na Grécia Antiga, por exemplo, o mercado e as trocas não tinham a importância enquanto atividade lucrativa que ganharam mais tarde e que têm hoje. Conforme ele ressalta, "neste período, a oikonomia significava o processo de provisão material da casa (oikos) e o mercado era apenas a forma de se organizar as sociedades de subsistência, não sendo grande o bastante para organizar a vida social como um todo".

Veremos daqui a pouco, no entanto, que o mercado aparecerá nas análises de Hegel e Marx acerca da organização da sociedade, e que ele não é dissociado da esfera da sociedade civil como é hoje, largamente, para mídia e senso comum, e, em parte, para o meio acadêmico. Wapner (1997:77), por exemplo, ao falar de sociedade civil global, não aparta o mercado de sua definição, o que veremos daqui a pouco.

Continuemos nossa breve análise da evolução do termo sociedade civil, contudo, tratando agora de como surgiu a distinção entre essa esfera e a do Estado. Foram dois contratualistas - Locke e Montesquieu - os primeiros autores a quase promover tal separação, segundo colocam Cohen e Arato (1997:89 apud Saraiva, 2003:35). 
Locke cria dois momentos: primeiro existe uma sociedade independente, e depois um contrato que a converte em uma associação civil ou governo. Além disso, o autor fala de proteção dos cidadãos contra o próprio governo quando este não for bom. Montesquieu, por sua vez, reparte os sistemas de governo em República, Monarquia e Despotismo.

No Despotismo, haveria uma lacuna entre o governo e o povo. Na Monarquia, a presença de corpos intermediários entre governo e sociedade tornaria possível o cumprimento da lei. Os corpos representariam os indivíduos atomizados, que, sozinhos, não podem se confrontar com o Estado. Portanto, é possível dizer que o autor fala de uma repartição entre Estado Civil e Estado Político. Saraiva (Ibid:35) não deixa de frisar, no entanto, que os corpos a que Montesquieu se refere não podem, nem de longe, ser comparados com entidades não-governamentais contemporâneas, uma vez que o autor era monarquista, e que tais corpos eram “entidades meramente aristocráticas”.

Ainda de acordo com Saraiva (Ibid:36), a efetiva partição entre os conceitos de sociedade civil e Estado ocorreu apenas a partir do século XIX. Poderíamos aventar como um dos motivos para tal separação a ascenção do absolutismo - concentração maior e maior de poder nas mãos de um soberano, centralização, inacessibilidade da esfera estatal para a sociedade. Também neste período se expandia a burguesia comercial, contribuindo para mais mudanças no conceito de sociedade civil. A esfera não-governamental, a partir do absolutismo, passa a ser valorizada como freio ao poder centralizado. O desenvolvimento do capitalismo, o fortalecimento de uma esfera de livre iniciativa como a do mercado, constitui outro fator de valorização da ação nãogovernamental. Três autores vão construir concepções, então, já considerando Estado e sociedade civil como esferas apartadas: Hegel, Marx e Gramsci (Saraiva, Ibid: 37-42).

Hegel constrói um conceito de sociedade civil como o de uma esfera capaz de organizar o que ele chamou "sistema de necessidades" dos indivíduos, unindo-os em torno de objetivos comuns. Fariam parte de tal sociedade civil indivíduos, classes, grupos e instituições, não sendo excluído o mercado. É interessante destacar, entretanto, o Estado constitui o nível mais complexo de organização social, e a sociedade civil seria um momento de evolução até ele. Marx critica a concepção hegeliana, afirmando que as instâncias intermediárias - a organização em torno do "sistema de necessidades", que para Hegel atua fortalecendo o espírito público - são, na verdade, outra forma de subjugação das classes trabalhadoras. 
Antonio Gramsci também se debruçou sobre o tema, concordando com a crítica feita por Marx ao ordenamento burguês. Para ele, existem na sociedade dois planos superestruturais distintos e relativamente autônomos, mas inseparáveis na prática. Um desses planos é a sociedade civil, que congrega partidos, organizações sociais, meios de comunicação, igrejas, empresas, etc. O outro é a sociedade política ou Estado, que são as instituições governamentais, Forças Armadas, etc (Seremeraro 1997:74 apud Saraiva, Ibid: 42).

Em se falando da sociedade civil contemporânea, no entanto, não podemos ficar com nenhum desses conceitos. E isso porque houve um resgate do termo nos últimos anos para apresentá-lo sob uma nova ótica. Essa nova ótica teria ascendido face à degeneração/insatisfação com o aparato estatal. Dagnino (2002:9 apud Saraiva, Ibid:45), por exemplo, propõe que o renascimento conceitual do termo teria suas raízes na luta contra o autoritarismo. Para o autor, a insurgência contra regimes autoritários governos comunistas no Leste Europeu, ditaduras na América Latina - “contribuiu para uma visão homogeneizada da sociedade civil, que deixou marcas profundas no debate teórico e político sobre o tema”.

Não é apenas nos regimes autoritários, no entanto, que se pode fazer essa ligação entre a emergência de um novo conceito de sociedade civil e a insatisfação com o papel do Estado. Nas democracias consolidadas, tal relação também existiria. Saraiva (Ibid:46) fala de críticas que surgiram, na década de 1970, ao Estado de Bem Estar Social, modelo que vigorava nas democracias da Europa pós-II Guerra Mundial. O teor dessas críticas, de acordo com o autor, ia no sentido de que "todos os laços de solidariedade social autônomos estavam sendo destruídos como conseqüência da intervenção administrativa na sociedade pelo Estado de Bem Estar capitalista”.

Havia, portanto, um criticismo ao Estado e ao mercado, e uma exaltação da sociedade civil, que poderia resolver a questão dos resultados insatisfatórios apresentados por ambos, sendo de extrema importância para um País. Outra coisa que é importante citar é o descontentamento, também, com sistemas representativos como os partidos políticos, e os processos de recuo da presença do Estado por quais passaram vários países nos anos 1980 e 1990 (Saraiva, Ibid:9). A redução da ação do Estado abriu caminho para a repartição da prestação de serviços públicos com a sociedade civil. Dentro dessa interpretação mais recente de sociedade civil, ela abarcaria associações e movimentos voluntários independentes do Estado e do mercado. Nesse contexto, as entidades que, hoje, se reúnem sob o nome ONGs, tendo algumas características a 
distingui-las, “aparecem como uma novidade em termos de prática associativa, de ação coletiva e de relacionamento com o Estado” (Saraiva, Ibid:10). Cada vez mais presentes na realidade cotidiana, elas têm agregado competência técnica, fato que, conjugado ao processo de declínio por que passam partidos políticos e parlamentos, reforçou a crença de que tais organizações vêm suprir as deficiências do Estado e corrigir as distorções provocadas pelo mercado.

Se formos nos basear na negação implícita no termo Organizações NãoGovernamentais para tentarmos saber quem são esses atores tão presentes, tão comentados no mundo contemporâneo, teremos um problema, já que isso abre espaço para uma gama de organizações com propósitos, estruturas e formas de ação as mais diversas. É por isso que, após fazer algumas considerações teóricas acerca da sociedade civil global, vamos tentar falar um pouco mais das características dos atores chamados ONGs. Em seguida, trataremos rapidamente das redes e da cooperação, que constituem um dos traços mais marcantes da organização desses atores na sociedade global de hoje.

\section{2 - Sociedade civil global}

O desenvolvimento tecnológico dos últimos anos, o grau de eficiência e a rapidez que alcançaram comunicações e transportes, integraram o mundo de tal forma, que "qualquer fato político relevante pode ter repercussão imediata em todo o mundo, despertando a opinião pública e influenciando o cenário internacional”, conforme colocou Almeida (1995:11). Tal integração é descrita sob a palavra de domínio corrente globalização.

No que diz respeito ao âmbito teórico das relações internacionais, podemos afirmar ter havido uma mudança com relação ao paradigma dominante na área. A proliferação de atores outros que não apenas os Estados no sistema internacional criou uma sociedade transfronteiriça bastante complexa. Segundo Viola (1996:16 apud Villa, 2001:66-67), “existe uma passagem do sistema internacional para o sistema globaltransnacional-bifurcado. O sistema internacional era Estado-cêntrico. O sistema globaltransnacional-bifurcado é simultaneamente Estado-cêntrico (não hegemônico como superpotência militar) e multicêntrico alta diversidade de atores-forças sociais, como corporações transnacionais, organizações não-governamentais, organizações intergovernamentais, comunidades epistêmicas e mídia-formadores de opinião”. 
Smouts (Ibid: 144) fala sobre a existência, em caráter mundial, “de um espaço público no sentido de Habermas”, onde os diferentes componentes se comunicam. O trecho abaixo também ilustra bem o que queremos dizer:

"Vive-se um momento histórico em que as lutas sociais ou os princípios éticos que as orientam tendem a se transnacionalizar face ao desenvolvimento da comunicação” (Scherer-Warren, 1995:76 apud Inoue, 1995:6).

Para Wapner (1997:73), a sociedade civil global constitui uma estrutura que opera acima do indivíduo, abaixo do Estado $e$ além das fronteiras estatais. Como ele coloca, "human interaction troughout the world is not contained within the territorial borders of the state”. O que teria possibilitado esse alcance global da sociedade civil seriam fatores como a interpenetração dos mercados, o desenvolvimento das tecnologias de comunicação, a propagação de objetivos transnacionais.

Cabe lembrar, aqui, um pouco do contexto histórico da emergência dessa sociedade civil global, e falar das implicações desse novo cenário para os estudos das relações internacionais. Como já dissemos, houve alguns ensaios tímidos no sentido de participação de atores não estatais no sistema internacional no fim da II Guerra Mundial. As chamadas ONGs foram admitidas como observadoras no Conselho Econômico e Social (ECOSOC) durante os trabalhos de criação das Nações Unidas em São Francisco. Entretanto, vigorava ainda o paradigma realista das relações internacionais, com os Estados como atores únicos e soberanos na defesa do interesse nacional.

Uma percepção diferente demorou alguns anos a acontecer. Imediatamente após a II Guerra, o mundo mergulhou na Guerra Fria entre Estados Unidos e União Soviética e na ordem bipolar. Continuava vigorando a idéia do Estado como gestor único das relações internacionais, defendendo seus interesses. Acima de todos estava a segurança, com um cunho essencialmente estratégico-militar.

Villa (2001:65) afirma que, a partir do recuo dessas preocupações militares, temas como meio ambiente, direitos humanos, migrações, explosão demográfica, narcotráfico e outros puderam ganhar a agenda internacional. Tais questões, para o autor, têm um caráter societal. Assim, "sua especificidade reside antes no funcionamento de uma sociedade civil cada vez mais transnacionalizada do que no 
próprio Estado” (Ibid). Isso, para o autor, resultou no relaxamento da soberania estatal e na possibilidade de penetração de outros atores no sistema internacional.

Difícil delimitar precisamente quem são esses atores. Para Wapner, por exemplo, compõem a sociedade civil global atores da esfera econômica - empresas transnacionais, por exemplo. Para ele, ONGs são “international scientific bodies, multinational corporations (MNCs), transnational political activist groups, religious associations, and all other voluntary affiliations that organize themselves or at least project their energies across national boundaries” (Wapner, 1997:75). Entretanto, principalmente as entidades que hoje se auto-denominam ONGs, rejeitam fortemente essa abordagem, que inclui entre elas entidades cuja finalidade é o lucro. Segundo Saraiva (2003:12), “embora não haja uma definição conceitual do que vem a ser uma ONG, algumas entidades são vistas e se vêem enquanto ONGs”. Elas são assim vistas pelos governos, pelos organismos multilaterais, pela mídia, segundo o autor, e "são consideradas como sendo de interesse público". Visam o bem comum, portanto, uma das principais características que se arrogam aqueles atores que o senso comum reconhece, atualmente, como merecendo a denominação de ONGs. E são esses os atores que nos interessam neste trabalho.

É bom ressaltar, entretanto, o quanto a diversidade de atores, hoje, torna a sociedade civil global difícil de compreender e delinear em sua dinâmica e mecanismos. No balaio de gatos dos atores não estatais, podem ser incluídos até mesmo aqueles que representam uma ameaça à paz e à segurança mundiais - como grupos terroristas, ou quadrilhas de ilícitos transnacionais. São muitos os personagens que querem dividir a cena com os Estados.

Keohane e Nye (1977:23-27 apud Almeida, 1995:12), precursores da teoria globalista - o paradigma que contestou e segue contestando o realismo, no âmbito do terceiro grande debate internacional, iniciado nos anos 1970 - criaram o conceito da existência de uma interdependência complexa entre os atores do sistema internacional. Três fatores teriam contribuído para a configuração de um quadro no qual figura essa interdependência: 1) a existência de canais múltiplos que permitem maior contato formal ou informal, direto ou por recursos de telecomunicações, entre as sociedades 2) ausência de uma hierarquia na agenda política internacional 3) declínio do uso da força militar na solução dos problemas.

Neste cenário, “os Estados têm que lidar com o desafio da ausência de hierarquia na agenda e de sua constante variação. Outro desafio seria a capacidade que 
têm outros atores não-estatais de definir objetivos para assuntos da agenda” (Almeida, Ibid:13).

O fato de os atores não-estatais ajudarem a definir a agenda, entretanto, não elimina a assimetria existente entre atores do sistema internacional. Grande parte deles, por exemplo - caso das próprias ONGs - não têm personalidade jurídica internacional. Além do que, embora os atores possam influenciar, são os Estados, em última instância, que atuam na construção da regulação internacional. Nos é útil, aqui, o conceito de governança global de Rosenau (1997 apud Smouts, 2004:144), segundo o qual governança constitui um conjunto de regulações que funciona, mesmo não emanando de fontes oficiais. Tal é o contexto a cercar as chamadas ONGs, nosso objeto de estudo.

\section{3 - Sobre as ONGs}

A denominação Organização Não-Governamental, expressa pela sigla ONG em português, foi cunhada pela ONU na época de sua formação, e é utilizada para se referir a entidades com as características e objetivos às vezes bastante diversos entre si. Entre as ONGs que são consultoras do ECOSOC da ONU estão, por exemplo, da Anistia Internacional à União dos Consumidores e à Associação Internacional dos Chefes de Polícia (Inoue, 1995: 49).

Como já dissemos, as coisas ficam ainda mais complicadas se tentarmos definir Organizações Não-Governamentais com base na negação implícita no termo - tudo aquilo que é não-estatal. Afinal, tal característica abarcaria também as organizações com fins lucrativos. Ora, isso vai contra o conceito mais recente e difundido sobre a sociedade civil e suas organizações, a nova concepção que permeia nossa sociedade atualmente, segundo a qual a sociedade civil seria a esfera das ações cidadãs e que não têm o lucro por objetivo.

Como colocou Saraiva, entretanto, (2003:12), “conquanto não haja uma definição consensual do que vem a ser uma ONG, algumas entidades são vistas e se vêem enquanto ONG”. E, ainda, segundo Landim e Cotrim (94: Introdução apud Saraiva, Ibid: 68), ONGs constituem uma categoria que vem sendo “construída socialmente” e que designa um grupo de entidades com características peculiares “reconhecidas pelos seus agentes, pelo senso comum ou pela opinião pública”. Tais características seriam as de serem elas entidades civis e sem fins lucrativos. 
Essas duas designações, no entanto - civis e sem fins lucrativos - deixam ainda uma ampla gama de entidades diversas entre si à escolha. Igrejas, clubes de vizinhança, grupos de bairro, por exemplo, podem apresentar essas duas qualidades.

Na tentativa de encontrar um conjunto de características que fossem o mais fiéis possível às especificidades das entidades das quais pretendemos tratar, escolhemos, para este trabalho, uma proposta de conceito feita por Cristina Inoue. Reunindo diversas peculiaridades acerca dos grupos que se auto-denominam ONGs e que hoje são comumente aceitos como tais, Inoue chegou à descrição de um grupo de organizações que fazem parte, ou são um sub-setor, do chamado Terceiro Setor - o setor que não é mercado nem Estado - e que se distinguem de movimentos sociais, partidos políticos, igrejas, associações de bairro, associações profissionais, entre outros. Segundo a concepção resultante,

“ONGs são associações civis, cujos fins são, em geral, públicos e se formam em torno de valores como justiça social, democracia (nos seus vários sentidos político, econômico, social), direitos humanos, paz, ou valores como sustentabilidade ecológica, igualdade nas relações mulher-homem, negro-branco etc. Possuem estruturas organizativas definidas, Seus membros realizam, em geral, um trabalho profissionalizado. Utilizam, principalmente, meios comunicativos. São formações inerentemente políticas. Constituem o sub-setor mais transnacionalizado do terceiro setor e têm buscado influenciar a condução dos eventos globais, bem como a formação de uma opinião pública e consciência globais”. (Inoue, 1995:55)

\section{4 - Redes e cooperação}

A grande tendência de atuação das ONGs no âmbito da sociedade global hoje existente é a organização em redes. Korten (1990:98 apud Inoue, Ibid: 61) afirma que as ONGs do Norte e do Sul firmam parcerias, em que as primeiras contribuem para o fortalecimento das segundas.

A articulação em redes também pode estar ligada à necessidade de troca de informações e experiências, e ao desejo das ONGs de fazerem face a um cenário global altamente complexo. Segundo Scherer-Warren (1995:178 apud Inoue, Ibid), as redes têm sido vistas pelas ONGs como estratégia para passar do micro ao macro, do local ao global. Já segundo Inoue (Ibid:65), a formação de redes de entidades está ligada a 
fatores como "desafios globais que elas se propõem a enfrentar e à necessidade de compartilhar recursos”, recursos esses muitas vezes escassos, como coloca a autora. Cabe colocar que esse processo - de organização em redes - é facilitado, e muito, pelas evoluções tecnológicas no que diz respeito às comunicações e transportes.

Mance (2000:24), por sua vez, afirma, ao falar de redes de ONGs, que "todo o conjunto de ações solidárias (...), ao considerar o setor público não-estatal, tende aos poucos a se conectar em grandes redes a partir de fóruns e de outros mecanismos para comunicação, deliberação e ação articulada”. O autor destaca, ainda, a particularidade das redes de funcionarem, segundo ele, como um sistema autopoiético, já que elas seriam um sistema aberto que se auto-reproduz. Assim, “a idéia de rede que conecta grupos de um determinado movimento social, por exemplo, do movimento de mulheres, é a de que a articulação entre todos os movimentos do tipo fortaleça aquele movimento em particular pelos intercâmbios que passem a ocorrer entre eles” (Ibid).

No caso específico das parcerias entre Sul e Norte de que falamos, entretanto, há uma particularidade por trás da questão da formação de redes, a da intenção de fortalecimento e desenvolvimento das entidades do Sul. As chamadas ONGs do Norte, mais institucionalizadas e profissionalizadas, têm aceitado e vivido um processo de transferência de conhecimento, experiência e tecnologias para as ONGs do Sul. Tal processo é considerado válido por ambas as partes, e tem feito surgir redes informais baseadas na autonomia, pluralidade, confiança mútua. No entanto, é importante destacar, como lembra Inoue (Ibid: 62), que “as relações entre as ONGs do Sul são ainda incipientes, comparadas àquelas entre as do Norte e as do Sul”. Muitas ONGs do Sul, de fato, clamam a necessidade de maior articulação regional. Além disso, embora a contribuição das entidades do Norte seja bem vinda pelas ONGs do Sul, abertas às parcerias, a relação entre as duas partes não é de todo tranqüila. O trecho abaixo, de Brodhead (1992:122), ilustra bastante bem este ponto:

“Algumas ONGs do Sul reclamam de enfrentar uma relação essencialmente desigual, em termos de poder, com as ONGs do Norte. Afirmam que estas são excessivamente burocratizadas e adotam um enfoque de cima para baixo, no qual os projetos idealizados por pessoal do Norte nem sempre são os que melhor se adequam às necessidades, tradições e culturas locais. Sabe-se, também, que muitas ONGs não atingem, de fato, os mais pobres e menos poderosos, preferindo, em vez disso, trabalhar com grupos mais fortes ou mais organizados”. 
Um outro aspecto que é importante destacar é que a atuação internacional das ONGs do Sul é muito mais tímida do que a verificada entre as ONGs do Norte. Embora não ignorem a importância de terem em suas agendas o que se passa no cenário global, e embora haja iniciativas de articulação entre elas, a atuação das ONGs do Sul ainda é voltada mormente para influenciar as políticas e ações de seus governos locais. O lobby na arena internacional, afirma Clark (1991:145-146 apud Inoue, 1995:63) tem sido dominado por ONGs do Norte.

Acompanhando as atividades - destacadamente a atuação internacional - da ABONG, que escolhemos como objeto de estudo para este trabalho, pretendemos verificar se procede essa idéia da organização em redes e dos acordos de cooperação entre as principais formas de ação internacional e com que objetivo se dão as parcerias por ela firmadas. 


\section{Metodologia}

A nossa intenção neste estudo foi obter uma amostra de como se dá, primordialmente, a ação com algum cunho internacional da Associação Brasileira de ONGs, e fazer uma análise dessa ação à luz de fenômenos recentes como um cenário internacional complexo, a globalização e a existência de barreiras cada vez mais tênues entre acontecimentos e atores. Para determinar a forma como se dá a ação de cunho internacional da ABONG tínhamos que recorrer a uma fonte de descrição dessas ações. Em consultas à página da entidade na Internet - que traz informações sobre quem é a ABONG, seus parceiros, seus objetivos e características - concluímos que os relatórios de atividades da Associação seriam a fonte mais completa e passível de nos dizer o que queríamos saber: que atuações eram mais freqüentes em detrimento de outras; quantas tinham algum caráter internacional e quantas eram estritamente nacionais, etc.

Nossa opção foi pela análise desses relatórios - que trazem as atividades em que a Associação de alguma forma se envolveu consideradas as mais importantes por ela por um período de cinco anos. A opção pelo intervalo de tempo ocorreu pelo fato de tratar-se de período suficiente extenso para que pudéssemos ter uma idéia da continuidade das ações e de quais eram mais recorrentes na agenda da ABONG. Um intervalo superior, de 10 anos, por exemplo, configurou-se inviável em razão da quantidade de páginas dos documentos, do enorme volume de ações a serem analisadas e do tempo de que dispúnhamos para conclusão da presente pesquisa.

Escolhemos os relatórios que englobavam o período de 1999 - quando os documentos começam a ser disponibilizados na Internet - até 2003. Optamos por seguir de 1999 em diante simplesmente porque tratava-se de um marco inicial, e não tínhamos qualquer ação de referência para que pudéssemos escolher um outro ano como ponto de partida. Acreditamos não ter a análise ficado prejudicada pelo fato de termos parado em 2003, uma vez que nada indica terem ocorrido mudanças profundas na essência das políticas, princípios, diretrizes da ABONG e na maneira de implementá-los desde então.

Além da análise documental, buscamos também estabelecer contato com representantes da Associação Brasileira de ONGs. A advogada e coordenadora do escritório de Brasília da entidade, Lisandra Arantes Carvalho, respondeu a perguntas de caráter mais institucional - principais características e diretrizes da ABONG. Já 
questões acerca das ações de cunho internacional da ABONG, e dos objetivos destas, foram respondidas por Taciana Gouveia, integrante da Diretoria Executiva da Associação.

Cabe ainda, antes de encerrar esta seção, fazermos breves considerações acerca da estrutura dos relatórios da Associação Brasileira de ONGs, nossa fonte documental neste estudo. Esses documentos não têm um formato nem um tamanho padrão, sendo diferentes entre si. São cinco, ao todo. Um diz respeito a um biênio (1999-2000), dois a um período de um ano, cada um (2001 e 2002), e dois, ainda, dizem respeito a triênios (2001 a 2003 e 2003 a 2006). Isso tornou a análise bastante complicada. Ativemos-nos aos anos de nosso escopo de análise, com atenção à possibilidade de haver ações cruzadas e repetidas em dois documentos diferentes. Houve ainda outras dificuldades, e nos foi necessário, como já mencionamos na Introdução deste trabalho, escrever algumas páginas apenas para explicar os critérios para selecionar e descrever as atividades, que estão disponíveis imediatamente antes dos dois capítulos em que falamos das ações em si.

Dadas todas essas explicações, passaremos agora ao primeiro capítulo de nosso trabalho, que destina-se a fazer uma contextualização sobre como surgiram as ONGs no mundo e no Brasil, sobre seu universo legal, e, ainda, a tratar das principais características da ABONG. 


\section{Capítulo I}

\section{ONGs: história, personalidade jurídica, mecanismos de atuação junto à ONU,}

marco legal no Brasil e o surgimento da ABONG

Este é um capítulo de contextualização acerca de como surgiram aquelas entidades chamadas hoje Organizações Não-Governamentais, e sobre qual é de fato a sua situação legal, em especial no que tange à atuação internacional, já que, diferentemente dos Estados e OIs, elas não possuem personalidade jurídica face ao sistema de regulação global. Também falaremos sobre as características principais e o surgimento da Associação Brasileira de ONGs, nosso objeto de estudo.

A entidade cujas ações nos propusemos a analisar não é uma ONG de atuação internacional, o que perceberemos neste capítulo ao falarmos dela e de suas características. No entanto, uma vez que as ONGs em geral são também tema deste trabalho, é importante delinear, aqui, como funciona o trabalho daquelas organizações que têm uma atuação predominantemente internacional.

Além do que, ONGs que se definem como nacionais atualmente podem, elas também, credenciar-se junto ao Conselho Econômico e Social (ECOSOC) das Nações Unidas, o principal mecanismo formal de atuação dessas entidades no cenário internacional. A ABONG, ela própria, não é credenciada e não tem qualquer status junto ao Conselho. Entretanto, a Federação de Órgãos para Assistência Social e Educacional (Fase), uma de suas associadas, é credenciada com status especial falaremos daqui a pouco de cada uma das categorias para credenciamento.

Provavelmente por ser ela própria uma ONG, mas também uma rede de Organizações Não-Governamentais - congregando ONGs com os propósitos mais diversos - tivemos a impressão, em nossa análise, de que a ABONG tem uma atuação um pouco dispersa, uma plataforma muito ampla, voltada para um sem-número de temas. No caso específico de sua atuação com alguma ligação com a cena ou com atores internacionais, ela basicamente busca parcerias e troca de experiência (veremos com quem e porque motivos); posiciona-se sobre alguns temas da agenda, em especial se podem de alguma forma afetar diretamente o Brasil; e o seu contato com as instâncias internacionais regulatórias e com mecanismos formais de ação no cenário global praticamente inexiste. O que ela acaba fazendo com mais freqüência é manifestar apoio a associadas que se envolvem em atuação do tipo, e citar essas ações em seus relatórios, 
colocando a plataforma das associadas como a sua própria, como se tratassem-se de ações suas também pelo fato de endossá-las. Discorreremos sobre isso mais longamente no capítulo seguinte. Primeiramente, vamos falar do surgimento desses atores singulares chamados ONGs, de sua situação legal, de seus mecanismos de ação internacional, da situação jurídica específica das ONGs brasileiras e da Associação Brasileira de ONGs.

\section{1 - ONGs: breve histórico no mundo e no Brasil}

No final do século XVI, começam a aparecer grupos, em sua maioria religiosos, criados para ajudar vítimas de conflitos ou desastres naturais. Posteriormente, na Inglaterra, surgem as primeiras normas regulamentando atividades de caridade em 1.601, descritas no Elizabethan Statute of Charitable Uses (Tavares, 1999:31). O autor fala desses grupos, dessas organizações privadas sem fins lucrativos, como os precursores das entidades que hoje chamamos de ONGs. Com a expansão posterior do colonialismo nos séculos XVIII e XIX, coloca ele, ganharam impulso grupos missionários, que levavam muitas vezes educação e assistência à saúde aos lugares onde atuavam, mas serviam, não se deve deixar de frisar, às administrações coloniais. Ao longo do século XIX, interesses mais diversos, além da assistência caritativa, passam a ser os responsáveis por unir as pessoas em associações - comércio, ciência, cultura, promoção das mulheres, situação das crianças, entre outros.

Em 1914, às vésperas do início da I Guerra Mundial, descreve Tavares (Ibid:32), existiam 330 organizações privadas sem fins lucrativos, com pessoas reunidas em torno de temas e interesses os mais diversos. Os grupos religiosos e caritativos já não eram maioria. Um fato curioso é que algumas dessas organizações privadas criadas no século XIX vieram a tornar-se OIs - caso do Escritório Internacional de Educação. Depois, ao longo da I Guerra Mundial, durante os anos de conflito, muitas das associações desapareceram. Finda a guerra, entretanto, ganharam força associações pacifistas, ou com o intuito de auxílio às vítimas.

A Liga das Nações, diz Tavares (Ibid:34-35), foi marco importante no estabelecimento de um relacionamento entre as Organizações Não-Governamentais que então não tinham ainda esse nome - e os organismos internacionais, as OIs. O Pacto de formação da liga previa a anexação a esta de todos os escritórios internacionais formados por tratados ou convenções diplomáticas. Posteriormente, em uma interpretação mais abrangente do artigo 24 do Pacto, que tratava da anexação dos 
escritórios, a Liga permitiu a anexação também das organizações privadas que assim o desejassem. Isso ocorreu em 1921. Em 1923, no entanto, a Liga das Nações volta a aceitar colocar sob sua patronagem somente os escritórios constituídos por acordos diplomáticos. Integrantes das organizações privadas, no entanto, são aceitos informalmente por um bom período na condição de assessores, participando do trabalho de comitês e comissões. Esta aceitação foi restrita posteriormente, e os assessores tornam-se correspondentes, que só podiam participar de reuniões a convite. Para o autor, o retrocesso é um prenúncio do que viria a ser a relação das ONGs com as Nações Unidas, com o papel das ONGs também mais restrito. Após a I Guerra, no período de 1919 a 1929, foram fundadas 300 organizações privadas sem fins lucrativos, e 31 organizações intergovernamentais.

Já ao fim da II Guerra Mundial, as organizações privadas sem fins lucrativos não participaram das reuniões preparatórias para a Conferência de São Francisco, onde foi constituída a ONU, mas prepararam, por conta própria, sugestões para a mesma. Por ocasião da realização mesmo da Conferência, o Departamento de Estado dos Estados Unidos convidou 42 a fazerem parte da delegação norte-americana na qualidade de consultoras. Mais 197 participaram por iniciativa própria como observadoras, sendo 160 norte-americanas, de acordo com Tavares (Ibid: 40).

Depois, ainda neste capitulo, falaremos mais detalhadamente dos mecanismos de participação das ONGs junto às Nações Unidas. Por hora, no entanto, basta dizermos que a participação formal das entidades no trabalho do organismo na ocasião ficou focalizada no artigo 71 da Carta das Nações Unidas. Este prevê que entendimentos para consultoria poderiam ser feitos com Organizações Não-Governamentais internacionais. Com as nacionais, só após consulta ao membro das Nações Unidas envolvido no caso. Cabe lembrar aqui também que a expressão Organização Não-Governamental foi cunhada pela ONU, para referir-se às organizações privadas sem fins lucrativos do tipo daquelas que admitia no ECOSOC.

E no Brasil, como se deu o surgimento das ONGs? A maioria dos autores estabelece como época em que apareceram as precursoras dessas entidades localmente a década de 1960, com crescimento em quantidade nas duas décadas seguintes, e com popularização do termo ONG junto ao senso comum e à mídia por ocasião da Conferência das Nações Unidas sobre o Meio Ambiente e Desenvolvimento, realizada em 1992 no Rio de Janeiro. Mais conhecida como Eco-92, ela teve participação massiva de ONGs e é apontada como um marco, com divulgação dessas entidades e de seu 
trabalho junto à opinião pública brasileira. A colocação dos anos 1960 como data do surgimento das primeiras ONGs no Brasil está ligada ao aumento da mobilização de trabalhadores através de sindicatos e do nascimento de movimentos sociais em especial anti-ditadura, com presença da Igreja Católica. Saraiva (2003:69), ao falar da década de 1960 como período de surgimento das primeiras Organizações Não-Governamentais localmente, no entanto, não deixa de frisar que muitos autores "fazem questão de ressaltar que as ONGs existem há muito tempo, mas tinham outros nomes”. E, de fato, Tavares (1999:32-33) fala da existência de associações privadas no Brasil já no período colonial - de caráter religioso e missionário, embora, sem características de movimentos - e, um pouco mais tarde, a partir da segunda metade do século XIX, do crescimento do movimento abolicionista com constituição de sociedades como as Caixas Emancipacionistas e a Confederação Abolicionista. Também surgiram, na época, sociedades comerciais e de assistência.

\section{2 - Personalidade jurídica das ONGs}

São os Estados os principais sujeitos do Direito Internacional Público. Além deles, cuja personalidade jurídica internacional resulta do reconhecimento por parte dos demais Estados, as organizações internacionais ou organismos internacionais - como ONU, Organização dos Estados Americanos (OEA) e outras semelhantes - também são sujeitos de direito na ordem global. Isto significa que podem ter direitos e podem assumir obrigações face à ordem internacional. As organizações internacionais são entidades intergovernamentais, criadas pelos Estados, e deles resulta a sua personalidade jurídica.

Com as ONGs, no entanto, é diferente. Enquanto a criação dos organismos internacionais é estabelecida por um ato entre Estados, um ato jurídico internacional, sendo organizações como a ONU instituições eregidas segundo as normas do Direito Internacional Público (Soares, 2000:22 apud Caresia, 2007:1095), as Organizações Não-Governamentais são criadas de forma exatamente oposta: nascem de atos jurídicos internos, segundo as normas internas de seus Estados de origem. A ONG é uma entidade coletiva nacional, mesmo aquelas de atuação internacional. A questão da personalidade jurídica das ONGs, que é nacional, fica bastante clara no trecho abaixo: 
"O fato de as Organizações Internacionais serem instituídas mediante acordo entre sujeitos de Direito Internacional exclui, de per si, que no conceito exposto possam ser incluídas formas de associação que não se constituem por meio de atos jurídicos internacionais, comumente designadas como Organizações Não-Governativas” (Bobbio, 1992:856 apud Caresia, Ibid:1096).

Como é possível, e o que regula, então, a atuação das ONGs - sujeitas à regulação nacional - em um cenário internacional? Primeiramente, cabe dizer que, reconhecida devidamente pela lei nacional, ela tem esse reconhecimento universalmente aceito. No Estado onde é formada, a ONG adquire personalidade jurídica. É verdade que, no caso de ONGs que têm escritórios em muitos países, ela pode ter que atender a requisitos suplementares - segundo cada lei nacional - para atuação em cada lugar onde deseja atuar. Entretanto, a sua personalidade jurídica primária vem de seu país de origem.

Da mesma forma, quando age no âmbito dos organismos internacionais, a ONG tem que sujeitar-se às regulações impostas por tais organismos, e, portanto, sujeitar-se ao Direito Internacional Público, o que não muda o fato de que possui personalidade jurídica nacional. Um dos mais clássicos exemplos de sujeição das ONGs às normas das organizações internacionais são os mecanismos para atuar junto ao ECOSOC e a outras instâncias às quais elas podem recorrer nas Nações Unidas, e é sobre isso que falaremos a seguir.

\section{3 - Mecanismos de atuação junto à ONU}

A possibilidade de obtenção de status consultivo junto ao ECOSOC por parte das ONGs constituiu o primeiro dos mecanismos formais de participação dessas entidades nas Nações Unidas. Tal mecanismo está previsto na Carta das Nações Unidas assinada em São Francisco, em 1945. Novos mecanismos apareceram de lá para cá, no entanto, e houve modificações nas regras para atuação das Organizações NãoGovernamentais junto ao Conselho Econômico e Social da ONU.

Primeiramente, vamos falar de como funciona a relação entre ONGs e ECOSOC hoje, e sobre o que mudou desde as regras originais até aqui. Começaremos reproduzindo o artigo 71 da Carta das Nações Unidas. 
Art.71. O Conselho Econômico e Social poderá entrar em entendimentos convenientes para consulta com Organizações Não Governamentais que se ocupem de assuntos no âmbito de sua própria competência. Tais entendimentos poderão ser feitos com organizações internacionais e, quando for o caso, com organizações nacionais, depois de efetuadas consultas com o membro das Nações Unidas interessado no caso ${ }^{2}$.

Pois bem: este artigo e os acordos e resoluções firmados no âmbito do ECOSOC - que é composto por 54 países - têm determinado, mormente, a relação da Organização das Nações Unidas com as ONGs. E, no ano de 1996, após cerca de três anos de discussões essa relação é revista. Essa revisão veio por meio das resolução 1996-31 e decisão 1996-297 do Conselho Econômico e Social.

A resolução 1996-31, entre outras coisas, agilizou o processo de solicitação do status consultivo junto ao ECOSOC por parte das ONGs e, ainda, decidiu que ONGs nacionais estariam aptas, a partir de então, a solicitá-lo. Em verdade, a resolução 199631 veio alterar regras e procedimentos previstos pela resolução 1296 do Conselho Econômico e Social das Nações Unidas, de maio de 1968. Ela não só tornou mais rápido o processo de obtenção do credenciamento e permitiu às ONGs nacionais, locais e regionais a solicitá-lo, como também criou mecanismos facilitando a participação dessas entidades em conferências da ONU.

De acordo com Tavares (1999:60), as resoluções do ECOSOC desde os anos 1950 admitiam a possibilidade de as ONGs participarem de conferências internacionais das Nações Unidas. Mas, coloca ele, “os textos vigentes até 1996 limitavam-se a breve menção ao assunto, levando as ONGs a serem tratadas caso a caso pelo órgão responsável pela preparação ou pelos preparativos de cada evento”. A resolução 31 de 1996, contudo, diz ele, refere-se "longamente à participação das ONGs em conferências internacionais, estabelecendo, em particular, critérios detalhados para o credenciamento das organizações sem status consultivo junto ao Conselho” (Ibid:63).

Segundo Pellaes Neto (2003), a mudança - que começou a ser debatida através da formação de um grupo de trabalho com este fim, em 1993 - “advém da experiência de recentes conferências da ONU, nas quais muitas ONGs, acreditadas como nacionais, demonstraram perspectivas e programas de ação de âmbitos internacionais. As condições de seus países ou regiões de atuação as leva, com profundidade, a discussões

\footnotetext{
${ }^{2} C f$. www.onu-brasil.org.br, acesso em 2 de janeiro de 2008.
} 
de assuntos de importância global”. Já Vieira (2001:130 apud Caresia, 2007: 1104) cita “o novo interesse recíproco entre ONU-ONG, e a participação cada vez mais massiva das ONGs nas conferências”, o que “contribuiu para a decisão do ECOSOC para promover a revisão geral do sistema da ONU para consulta com as ONGs”.

De fato, uma outra mudança que resultou da revisão efetuada em 1996 encontrase expressa na decisão 297 do ECOSOC naquele ano. Esta recomendou que a Assembléia Geral da ONU examinasse, em sua $51^{a}$ sessão, a questão da participação das ONGs em todas as áreas de trabalho das Nações Unidas - e não só nas áreas de atuação do Conselho Econômico e Social. Como resultado disso, diz Caresia (Ibid), foi criado, dentro do Grupo Especial de trabalho da Assembléia buscando o fortalecimento do Sistema ONU, um subgrupo de ONGs com o objetivo de "examinar os problemas de acesso das ONGs, particularmente em respeito à Assembléia Geral”.

Trataremos agora rapidamente de como funciona a admissão e permanência no ECOSOC e quais os tipos de status consultivo que as ONGs podem obter, antes de falar de outros dois mecanismos de participação junto às Nações Unidas voltados especialmente para as ONGs - o Departamento de Informações Públicas e o Serviço de Enlace Não-Governamental das Nações Unidas.

Cabe-se saber primeiramente, a respeito do credenciamento junto ao Conselho Econômico e Social, que este pode dar-se junto a uma de três diferentes categorias. São elas:

- Organizações com status consultivo geral: para ONGs cuja atuação se refira à maior parte das agendas do ECOSOC.

- Organizações com status consultivo especial: para ONGs que tenham especial competência em algum campo de atividade do ECOSOC.

- Organizações com status roster: para ONGs cuja competência as credencie a dar contribuições ocasionais ao trabalho da ONU.

As ONGs que desejarem credenciar-se ao Conselho com um desses status devem enviar uma solicitação que será analisada pelo Comitê Intergovernamental para ONGs do ECOSOC, formado por 19 países. A recomendação é enviada ao Conselho Econômico e Social, a quem cabe a palavra final. Entre os requisitos exigidos para ter a solicitação aprovada estão que as atividades da ONG tenham relação com as do ECOSOC, que esta conte com mecanismo democrático de tomada de decisões, que esteja reconhecida oficialmente por seu Estado, e que tenha sido criada pelo menos dois 
anos antes do pedido de credenciamento. Se conseguir ser credenciada com status geral ou especial, a ONG tem que enviar um relatório anual de suas atividades ao ECOSOC. Este pode revogar o registro de entidades que não o apresentem, ou descumpram requisitos, ou que ajam de forma contrária aos objetivos da Carta das Nações Unidas.

Segundo informação de Caresia (Ibid: 1106), em 2005 existiam cerca de 3 mil Organizações Não-Governamentais com algum tipo de status junto ao Conselho Econômico e Social da ONG. Destas, um número muito reduzido - apenas 12 - são brasileiras. Destas, seis possuem status consultivo especial, uma possui status consultivo geral e cinco têm status roster.

Além do ECOSOC temos, ainda, mais dois mecanismos de participação para Organizações Não-Governamentais junto às Nações Unidas. São eles, como já mencionamos, o Departamento de Informações Públicas e o Serviço de Enlace NãoGovernamental.

O primeiro foi criado em 1946, por resolução da Assembléia Geral da ONU, com o objetivo de apoiar programas e instituições governamentais ou nãogovernamentais com interesse em difundir informações sobre as atividades das Nações Unidas. Deve facilitar o acesso a publicações, filmes, pôsteres e outras espécies de material. Em 1968, o ECOSOC, por meio da resolução 1279, incumbe o Departamento de Informações Públicas de associar ONGs ${ }^{3}$. Já o Serviço de Enlace é um programa criado no âmbito das Nações Unidas em 1975, com o objetivo de facilitar a cooperação entre as ONGs e o sistema ONU. Ele financia e facilita a participação de Organizações Não-Governamentais em conferências e outros eventos das Nações Unidas. O Serviço envia, ainda, às ONGs registradas em sua base de dados, informes e boletins (Caresia, 2007: 1108).

As formas de participação junto às Nações Unidas estão entre as maneiras que as ONGs têm de ter alguma participação no processo decisório internacional. Trata-se de participação cerceada por limitações diversas, já que, como vimos, as ONGs não são detentoras de personalidade jurídica internacional, estando sujeitas, cada uma delas, às legislações de seus Estados de origem. E é sobre a legislação que regula a atuação das ONGs brasileiras que falaremos a seguir.

\section{4 - Marco legal das ONGs no Brasil}

\footnotetext{
${ }^{3}$ Seção DIP-ONG, disponível em www.un.org/spanish/aboutun/OMGs/welcome, acesso em 6 de janeiro de 2008.
} 
O termo ONG é inexistente na legislação brasileira. As entidades que são chamadas ONGs pelo senso comum, mídia e por alguns atores e autores em razão de determinadas características suas, têm a opção de se constituírem como entidades sem fins lucrativos. Há uma gama de entidades que podem ser enquadradas sob essa denominação, mas as ONGs, particularmente, constituem-se como associações civis sem fins lucrativos. Para assim constituírem-se devem ser criadas em assembléia geral, por um conjunto de cidadãos e possuir estabelecidos seus objetivos, finalidades, estatuto. A partir daí, podem requerer Cadastro Nacional de Pessoa Jurídica (CNPJ) junto à Receita Federal, e, ainda, registrarem-se junto à Previdência Social e aos órgãos competentes de seus locais de origem - estados, municípios. Uma característica que pode ser colocada como emblemática das associações civis sem fins lucrativos é o fato de serem autônomas - não estão sob o controle do Estado.

É nesse ponto, por exemplo, que elas diferem basicamente das fundações, um outro tipo de entidade sem fins lucrativos. As fundações podem ser públicas ou privadas. As públicas são constituídas a partir de patrimônio doado via ato do Poder Executivo. As privadas, por sua vez, são criadas a partir da doação de patrimônio por pessoa física ou jurídica, por meio de escritura ou testamento. Fundações públicas e privadas têm em comum o fato de terem caráter social e público e de estarem sujeitas à fiscalização do Ministério Público.

Mais recentemente, no entanto, uma novidade no que toca à legislação surgiu no horizonte das ONGs. Estamos falando da lei 9.709 de 1999, ou lei das Organizações da Sociedade Civil de Interesse Público (OSCIPs). Saraiva (2003:84) fala do desejo das associações civis brasileiras, na segunda metade da década de 1990, de “um marco legal mais específico (...) para que fossem diferenciadas de organizações como clubes de futebol, cooperativas etc., que também tinham fins 'públicos””. Ou seja, as ONGs gostariam de ter uma designação específica para o trabalho que realizavam

A lei 9.790 de 1999, ou lei das OSCIPs, foi feita após processo de discussão com representantes de Organizações Não-Governamentais. A iniciativa de criação de uma legislação que se destinasse a essas entidades sem fins lucrativos com características específicas partiu do governo. Este pediu que as entidades apontassem quais as principais questões que gostariam de ver contempladas. Havia interesse, por parte do poder público, em tornar mais acessíveis e menos burocráticos os meios de contratação dessas entidades para implementação de políticas e, como frisa Saraiva (Ibid:87-88) isso 
foi possível por meio da criação de um instrumento jurídico previsto na lei das OSCIPS: o Termo de Parceria, "mais ágil do que o convênio e o contrato”, que são "os mecanismos utilizados pela legislação anterior (...) para a transferências de recursos públicos para as organizações da sociedade civil”.

A partir da entrada em vigor da lei 9.790, várias entidades sem fins lucrativos que atuavam como ONGs - e eram constituídas como associações sem fins lucrativos solicitaram a qualificação de OSCIP ao poder público. Há um questionamento geral, no entanto - partindo representantes de ONGs e autores - sobre se não teria havido prejuízo da autonomia dessas entidades a partir do marco legal representado pela lei das OSCIPs. O trecho de Saraiva (Ibid:91) ilustra bem a questão:

“(...) na medida em que se vão tornando organizações para-estatais ou quaseestatais, sua legitimidade se desloca da sociedade civil para o Estado, sem deixarem de ser vistas como organizações da sociedade civil. Ou seja, elas 'nascem' naquela esfera, são consideradas como parte dela e legitimadas como tal, mas vêem cada vez mais se aproximando do Estado”.

A questão da manutenção da autonomia das ONGs frente ao acesso facilitado a parcerias e aos recursos do Estado trazido pela lei 9.790, o temor de que tal acesso esteja tornando as entidades constituídas no âmbito da sociedade civil meras executoras de projetos e prestadoras de contas ao governo é bastante interessante, mas não é o foco de nosso trabalho. Portanto, aqui, basta registrar que ela existe.

A ABONG, que participou da gestão das novas normas em duas rodadas de interlocução com o Estado, em 1997 e 1998, refere-se à lei das OSCIPs tendo buscado “reconhecer o caráter público de um conjunto de organizações da sociedade civil até então não reconhecido pelo Estado, criando novo sistema classificatório que procurou diferenciar organizações da sociedade civil sem fins lucrativos de interesse público daquelas de benefício mútuo e caráter comercial”. A entidade ressalta, no entanto, a baixa adesão de suas associadas à nova lei - até 2001, apenas 2,04\% tinha a qualificação de OSCIPs - e atribui o fato à "resistência por parte das associadas de se filiarem a uma legislação produzida no contexto de um governo que vê as ONGs muito mais como executoras e prestadoras de serviços do que como parcerias na elaboração, 
gestão e monitoramento de políticas públicas”4 Assim, podemos notar que, apesar de ter participado das discussões que antecederam a lei 9.790, a Associação Brasileira de ONGs não aprovou totalmente o novo marco regulatório tão desejado pelas ONGs.

Concluído o que tínhamos a dizer sobre a situação legal das ONGs no Brasil, passaremos agora a um breve histórico e descrição das características da Associação Brasileira de ONGs, para finalizar este capítulo.

\section{5 - Quem é a ABONG: surgimento e características}

A ABONG foi criada em agosto de 1991, com o objetivo, entre outros, de "promover o intercâmbio entre entidades que buscam a ampliação da cidadania, a constituição e expansão de direitos, a justiça social e a consolidação de uma democracia participativa”, conforme coloca sua Carta de Princípios ${ }^{5}$. Uma condição necessária para que uma Organização Não-Governamental brasileira associe-se à ABONG é ter uma atuação que esteja de acordo com os valores expressos na Carta de Princípios da entidade.

Ainda segundo a própria ABONG, no início dos anos 1990 as organizações da sociedade civil do Brasil detectaram a necessidade de "discutir as mudanças globais, o avanço do neoliberalismo, o processo internacional de reestruturação do capitalismo, a flexibilização produtiva, a globalização da economia, as reformas do papel do Estado, a mundialização da cultura, e, particularmente a conjuntura brasileira e a crise política do governo Collor, que resultou em seu impeachment” ${ }^{\text {. }}$

Uma visão ainda mais detalhada do contexto de surgimento da Associação Brasileira de ONGs nos é dada por Oliveira (1999:65-67). Ele relata a reação defensiva das Organizações Não-Governamentais brasileiras diante de medidas do governo Collor, como o congelamento das contas bancárias. Diante disso, essas entidades redigem um documento em 29 de março de 1990, que é encaminhado às principais agências de cooperação internacional. A mencionada carta das ONGs às agências de cooperação foi assinada por dez fóruns de ONGs. Abaixo, reproduzimos um trecho da mesma, excerto reproduzido também por Oliveira (Ibid):

\footnotetext{
${ }^{4}$ Cf. Qualificação como OSCIP, disponível em www.abong.org.br, acesso em 6 de janeiro de 2008.

${ }^{5}$ Cf. Carta de Princípios, disponível na página www.abong.org.br, acesso em 10 de janeiro de 2008.

${ }^{6} \mathrm{Cf}$. História, disponível na página www.abong.org.br, acesso em 10 de janeiro de 2008.
} 
“A natureza autoritária das medidas do novo governo leva-nos a imaginar a hipótese de ações repressivas contra os movimentos sociais e as ONGs. Diante de tal possibilidade, a cooperação internacional pode ser chamada a mobilizar-se pela defesa da legitimidade do direito dos organismos que tem apoiado no Brasil. Entendemos que as circunstâncias colocam também na ordem do dia a questão do auto-reconhecimento e da representação das ONGs, o que permitiria dar um tratamento adequado à exigência de reconhecimento público do universo das ONGs comprometidas com um projeto democrático e de apoio aos movimentos populares. A conjuntura torna assim imperiosa a aceleração do processo de articulação das ONGs brasileiras que vêm se desenvolvendo dos últimos anos”.

De fato, pouco tempo depois, principalmente por iniciativa de fóruns regionais de ONGs do Rio de Janeiro e do Recife, acelera-se o processo de consultas visando à constituição de uma Associação Brasileira de ONGs. A data da assembléia de fundação dessa nova entidade - 10 de agosto de 1991 - é justamente no dia seguinte à conclusão, do $1^{\circ}$ Encontro Internacional de ONGs e o Sistema de Agências das Nações Unidas, que aconteceu no Rio de Janeiro e teve como tema "Desenvolvimento, Cooperação Internacional e as ONGs”.

Á época, devido a um afastamento entre as ONGs e o governo brasileiro justamente em razão do estranhamento entre tais entidades e governo Collor - a Agência Brasileira de Cooperação (ABC), do Itamaraty, embora tenha co-patrocinado o evento, teve nele uma participação que "limitou-se a uma intervenção de boas vindas de seu diretor-executivo na sessão de abertura” (Oliveira, Ibid).

Ainda tratando de características da ABONG, ela hoje tem aproximadamente 270 associadas. Em 1991, quando foi criada, eram 108. Um levantamento feito pela própria entidade em 2004 traçando o perfil de suas afiliadas apontou que, do total de associadas à época - aproximadamente 250 - a maioria, 31,68\%, definia seu âmbito de atuação como nacional. Em seguida, vinham as que definiam sua esfera de atuação como estadual, constituindo $29,7 \%$ da totalidade, e, em terceiro lugar, ficavam as que definiam a sua ação como municipal $18,32 \%$. Um percentual mais reduzido declarou o seu âmbito de atuação como sendo regional (6,44\%), e apenas uma classificou sua ação como internacional $(0,5 \%)$.

Segundo a mesma pesquisa, 57,43\% das afiliadas da ABONG concentram-se no Nordeste; $46 \%$ na região Sudeste; 33,6\% no Norte; $26 \%$ estão no Centro Oeste e 
25,74\% no Sul do Brasil. Quanto às principais áreas temáticas priorizadas pelas organizações associadas, 47\% delas afirmaram concentrar suas atividades na Educação; 40,59\% disseram centrar-se na promoção da participação popular; 29,7\%, na Justiça e promoção de direitos; 26,7\%, no fortalecimento de outras ONGs e movimentos populares; 26,24\% afirmaram ter ação voltada para relação de gênero e discriminação sexual; 23\%, para o trabalho e renda; 22,2\% para a saúde; e 20\% para o meio ambiente. Tais foram as temáticas mais citadas pelas associadas.

Apresentamos estes números para dar uma idéia do perfil da ABONG, que afinal, é formado em alto grau também pelo perfil das associadas que a integram. Lisandra Arantes Carvalho ${ }^{7}$, advogada e coordenadora do escritório de Brasília da Associação Brasileira de ONGs, por nós entrevistada para este trabalho, chama a atenção para um aspecto quando se fala do crescente número de associadas da entidade. De acordo com ela, "existe a idéia de que a ABONG seria um sindicato das ONGs e que todas deveriam estar nele. Na verdade, a Associação é uma rede de entidades que guardam uma semelhança entre si e estão longe de ser a maioria das organizações nãogovernamentais brasileiras. Fala-se de 300 mil entidades ao todo, entre as que têm o CNPJ de associação, fundação, igreja”.

Descrevendo suas afiliadas como entidades que atuam "em diversas áreas, com diversos temas e públicos”, a Associação Brasileira de ONGs afirma que todas essas organizações, bem como ela própria, têm “um projeto político comum”, que é descrito como reunindo os seguintes objetivos:

- Luta pela radicalização da democracia, universalização dos direitos e pelo combate à pobreza, às desigualdades e a todas as formas de exclusão, discriminação e opressão;

- Atuação na formulação e no controle social das políticas públicas e pela ampliação da cidadania;

- Intervenção nas causas estruturais dos problemas sociais e de desenvolvimento;

- Construção de um projeto de desenvolvimento ambientalmente sustentável, socialmente justo e com igualdade racial e de gênero;

\footnotetext{
${ }^{7}$ Entrevista pessoal, concedida por telefone no dia 19 de fevereiro de 2008.
} 
- Articulação com os movimentos sociais e a participação em redes e fóruns da sociedade civil;

- Defesa da autonomia das organizações da sociedade civil e a transparência no uso dos recursos públicos ${ }^{8}$

Podemos perceber, portanto, que o conceito que tem a ABONG do que seria a sociedade civil, sua visão da própria atuação em articulação com suas associadas, encaixam-se bastante bem na noção contemporânea de sociedade civil como uma esfera que atua no sentido de buscar o interesse público e de corrigir distorções ocasionadas pela ação do Estado e do mercado. Já falamos anteriormente dessa noção, inserida no contexto do fenômeno que Saraiva (2003:45) chamou de "renascimento" do termo sociedade civil. O próprio autor, aliás (Ibid:95), ao falar da Associação Brasileira de ONGs, afirma que "o estatuto e o histórico da entidade confirmam todo o discurso atual sobre a 'sociedade civil'. A virtude, o altruísmo, as boas intenções, os valores universais e a vontade de transformar o mundo são recorrentes”.

Tendo tratado brevemente do que é a Associação Brasileira de Organizações Governamentais, de como surgiu e do trabalho que se propõe a fazer, e antes de passar para a análise dos relatórios de atividades da entidade, queremos falar rapidamente acerca da ABONG e do cenário internacional.

Quando cita entre objetivos seus a construção de uma sociedade mais justa, com menos desigualdades, em promoção do desenvolvimento sustentável, democratização, ampliação da cidadania, dentre outras coisas, a Associação não especifica se pretende atingir esses objetivos a nível global ou local. Entretanto, o exame da própria história da ABONG nos leva à percepção de que a luta da entidade tem se dado em alto grau na arena nacional, no sentido de impactar a realidade nacional. A quase totalidade de suas afiliadas - que gravitam em torno da Associação tendo com ela um projeto comum descreve sua ação, conforme vimos, como nacional, ou, ainda, regional, estadual ou municipal. Lisandra Carvalho, do escritório em Brasília, confirma que a atuação da entidade é “massivamente nacional”. E a Associação Brasileira de ONGs não é uma organização sem fronteiras, a exemplo de entidades como Greenpeace, WWF, etc. A ABONG tem fortes raízes e compromissos no Brasil. Entretanto, ela possui, sim, uma

\footnotetext{
${ }^{8}$ Cf. Seção Perguntas mais freqüentes, disponível na página www.abong.org.br , acesso em 10 de janeiro de 2008.
} 
relação com a cena internacional - do contrário não seria foco deste trabalho - pois não lhe é possível ignorá-la.

Um aspecto que podemos destacar, por exemplo, é que no momento de constituição da ABONG havia, como um dos principais focos, uma preocupação em resguardar a autonomia das entidades da sociedade civil frente a um governo cujas ações eram consideradas autoritárias e uma ameaça aos movimentos sociais. Entretanto, havia também uma atenção e uma preocupação com relação à conjuntura internacional naquele momento, segundo uma percepção da própria ABONG, que fala da necessidade de fazer face a uma época de "mudanças globais, neoliberalismo, avanço do capitalismo”. Além disso, há uma consciência da importância da existência de uma governança "lá fora”, além das fronteiras nacionais, à qual é possível recorrer contra esse autoritarismo - nos lembremos do documento enviada pelas ONGs às agências de cooperação internacional antes mesmo da constituição formal da Associação.

Isso se confirma em nossa análise de atividades recentes da ABONG. Ao longo de nossa observância dos relatórios de atividades organização em um período de cinco anos pudemos detectar uma grande preocupação da Associação e de suas afiliadas com a ação em âmbito local, voltada para as características e problemas peculiares à realidade brasileira. Por vezes, mesmo quando a Associação atuava em direção à cena ou a atores internacionais, era buscando objetivos locais. Pois bem, mesmo assim, mesmo com a preocupação com o foro nacional evidente, não sendo jamais perdida de vista, veremos, nos debruçando sobre as ações que fizeram parte de nosso estudo, que a Associação não perde de vista também a existência de um cenário internacional, mais do que palpável e presente em sua realidade.

Cabe dizer, então que, sim, a ABONG quer uma realidade nacional mais plural, mais justa, e grande parte de suas ações têm em vista a construção dessa realidade. Entretanto, há uma noção, durante todo o tempo, de que o que se passa "lá fora” influi no que se passa “aqui dentro”. Daí a atenção à esfera e aos atores externos.

O que poderíamos extrair disso tudo é que o fenômeno da globalização já não permite a nenhum ator a pretensão de construir uma agenda local que ignore a existência de uma agenda complexa internacional, de cuja construção participam, hoje, atores os mais diversos possíveis - já que partimos, neste trabalho, da premissa da existência de um espaço público internacional, de uma sociedade civil global. Passaremos, a seguir, nos dois próximos capítulos, à parte mais importante de nosso trabalho: a análise dos relatórios da ABONG. Antes de passar aos relatórios, no entanto, 
dedicamos algumas páginas a explicações necessárias sobre como se deu a análise e o porquê de ter se dado assim. 


\section{Breves explicações sobre os critérios que nortearam nossa análise}

Como dissemos, os dois capítulos que virão nas páginas a seguir deste trabalho constituem se cerne, sua parte mais importante. Trata-se da análise dos relatórios da Associação Brasileira de ONGs referentes ao período escolhido por nós, que trazem as principais ações com algum cunho internacional da Associação Brasileira de ONGs no dito intervalo de tempo.

As explicações que traremos aqui referem-se ao nosso método e aos critérios que nortearam nossa análise, necessários de serem expostos antes que passemos a ela propriamente dita. Os relatórios da ABONG trazem atividades e acontecimentos nos quais a entidade, suas associadas ou as regionais da Associação estiveram envolvidas, ou tiveram alguma participação no período de referência. A ABONG tem 270 associadas, como já vimos, e oito regionais (Regional Amazônia, Regional Centro Oeste, Regional Nordeste I, Regional Nordeste II, Regional Nordeste III, Regional São Paulo, Regional Sudeste e Regional Sul).

No caso da grande maioria das ações que não são propriamente da Associação Brasileira de ONGs descritas nos relatórios - são das associadas ou das regionais - a ABONG dedica espaço razoável a descrevê-las e, declarando apoiá-las ou acompanhálas, fala de tais atividades como se fossem suas próprias. Vale destacar que as ações de regionais ou associadas que entram nos relatórios da Associação Brasileira de ONGs, só por esse fato, podem ser consideradas quase todas marcadamente importantes para a mesma. São muitas as associadas que a entidade possui, e cada regional tem ações próprias, apóia e organiza atividades com as ONGs de sua região (as ONGs de cada região são associadas da ABONG, lembramos). Portanto, se uma atuação em particular entre tantas que não são propriamente da ABONG ingressa em um relatório merecendo longa descrição e atenção, é plausível supor que sua importância para a entidade não seja pequena. Nestes casos, portanto, contabilizamos as atividades citadas entre as ações da ABONG que entram em nossa análise.

Há uma exceção, no entanto, à situação descrita acima. Avaliamos que nem sempre as ações de terceiros mencionadas nos relatórios da ABONG podiam ser igualadas às próprias atividades da Associação. Em dois dos relatórios analisados - eles não seguem um padrão uniforme, como já expusemos na seção Metodologia deste trabalho - há um espaço que a Associação Brasileira de ONGs intitula Trabalho das Regionais, no qual são enumeradas ações destas. Essas atividades em específico não 
foram consideradas por nós como itens a serem contabilizados nesta análise. Primeiramente, porque elas aparecem apartadas daquelas realizações que a Associação Brasileira de ONGs coloca como suas, ficando em um espaço separado. Ora, outras ações, embora sejam de associadas ou regionais, aparecem no corpo mesmo dos relatórios, misturadas à atuação da ABONG, e foram essas que consideramos que a entidade encampa como se fossem suas próprias atividades. Além disso, as ações mencionadas na seção Trabalho das Regionais são por demais locais, específicas, e na maioria dos casos são citadas muito sucintamente, sem maiores detalhes. Por vezes a referência a elas é mesmo vaga 9 .

Por fim, há muitas ocasiões em que as ações descritas no espaço reservado ao trabalho das regionais repetem atividades já citadas no corpo dos relatórios - uma regional menciona ter participado de um seminário ou evento organizado pela ABONG, por exemplo, ou fala do stand que montou em uma das edições do Fórum Social Mundial. Neste caso, por óbvio, não poderiam mesmo ser consideradas como itens, porque são repetição de dados já naturalmente incluídos em nossa análise.

Um outro exemplo de coisas que não entraram como itens, além daquelas agrupadas na seção Trabalho das Regionais: em um dado momento, é citado em um dos documentos que basearam nossa análise o fato de ter sido iniciada a CPI das ONGs - um fato importante para as entidades, mas não uma ação da Associação Brasileira de ONGs e, portanto, não considerado um item. Quando o presidente da ABONG vai depor na referida CPI, no entanto, passamos a ter um item. Há também a questão do Fórum Social Mundial - os inúmeros seminários, oficinas, encontros que ocorreram no âmbito do evento também não entraram como itens, já que o Fórum foi considerado um item único. No entanto, muitas dessas atividades paralelas são citadas na relatório e a ABONG inclusive se alonga a descrever algumas. Ainda assim, optamos por deixá-las de fora e encarar o Fórum como uma ação só.

Por questões como essas, é importante destacar que não é nossa pretensão fazer, neste trabalho, um levantamento estatístico exato ao dividir os relatórios em itens e fazer um balanço dos tipos de ação de cunho internacional e de seu peso face à ação estritamente nacional. Não há qualquer pretensão a se chegar a dados numéricos exatos: o que teremos aqui é uma noção de quais as principais atividades de algum cunho

\footnotetext{
${ }^{9}$ Um dos relatórios, por exemplo, menciona que a Regional Nordeste 2 promoveu, em 2001, “diálogo com diversas articulações de ONGs e fóruns da região”, e não há qualquer informação sobre a que se referiu este diálogo, sobre quais os propósitos da ação citada, sobre qual o significado mesmo dela.
} 
internacional em que a ABONG se viu envolvida no período, e, no caso da comparação do número de ações de caráter internacional com o de ações estritamente nacionais, chegaremos apenas a uma delineação, ou uma aproximação, do peso de cada tipo de atuação com relação ao outro.

Uma outra razão pela qual não se pretende neste trabalho chegar a um balanço estatístico exato sobre a atuação da ABONG, é o fato de os relatórios referentes ao período de análise que escolhemos não terem todos o mesmo tamanho, nem seguirem um padrão único de conteúdo e organização deste ${ }^{10}$.

Assim, pela não-uniformidade no tamanho e ausência de um padrão nos relatórios, e também pelo fato de a divisão do texto corrido em itens ter sido um trabalho nosso, a nosso critério, não é possível extrair deles uma estatística confiável. O que pretendemos, como já dito, é apenas ter uma idéia do peso que teve para a ABONG, ao longo dos anos de análise, cada tipo de ação internacional, e o peso também das ações internacionais face às nacionais, a fim de tentar lançar uma luz sobre como se dá a atuação além-fronteiras da Associação Brasileira de ONGs e de qual a importância e tamanho dela.

Um outro aspecto da análise que é importante deixar claro, ainda, é que em diversos momentos as informações que os relatórios traziam eram incompletas - era citada uma atividade da ABONG no âmbito de uma parceria, por exemplo, e não havia explicação acerca do que significava tal parceria, sua história, objetivos, outros integrantes, etc. Portanto, tivemos que buscar em outras fontes essas informações a fim de tornar nossa análise mais substancial. Tais fontes foram, em muitas ocasiões, a própria página da ABONG na Internet; em outras, páginas de parceiros da Associação, de projetos, programas, outras entidades, etc.

Por fim, é precisa destacar também que a divisão que fizemos da atuação internacional da Associação Brasileira de ONGs por grupos de ação levou em contas as características que mais se destacavam em cada uma delas, já que cada atividade não

10 Esclarecemos já, na seção Metodologia deste trabalho, que a falta de um padrão uniforme nos relatórios foi uma das coisas que mais dificultou nossa análise. Dos cinco documentos referentes ao período de 1999 a 2003, um diz respeito a um biênio (1999-2000), dois a um período de um ano, cada um (2001 e 2002), e dois, ainda, dizem respeito a triênios (2001 a 2003 e 2003 a 2006). Há, ainda, o caso da seção Trabalho das Regionais, que só existe no relatório de atividades referente exclusivamente a 2001, e naquele que se refere exclusivamente às atividades de 2002. 
apresenta apenas uma única característica uniforme. O Fórum Social Mundial, por exemplo, é um evento, mas pela permanente articulação das entidades envolvidas com ele e pelas atividades paralelas e resultantes do Fórum, ele tem características também de parceria e rede e é considerado uma parceria pela própria ABONG. Foi a essas características que demos mais ênfase no momento de colocá-lo em um dos grupos da análise. Um outro exemplo que podemos citar é a rede Social Watch, de cuja coordenação brasileira associadas da ABONG fazem parte e que aparece citada em um dos relatórios. Por meio de parcerias com ONGs em vários países, a Social Watch compila dados sociais e monitora o cumprimento de tratados internacionais, e nos pareceu interessante destacar mais essa característica ao agrupá-la do que enfatizar seu lado parceria e resultados dessa parceria, e isso porque o monitoramento social para divulgação internacional aparecia, através da menção à Social Watch, pela primeira vez nos relatórios da ABONG.

Por fim, uma opção que fizemos a título de contextualização foi falar sobre ações ou acontecimentos que escapam ao período de análise quando julgamos isso relevante para melhor compreensão do assunto tratado, ou para que a informação não pecasse por incompleta ou por poder induzir a equívocos. Em todos os casos em que foi necessário realizar consulta em material que não os relatórios da ABONG, citamos nossas fontes. Todo o restante das informações, que não for citado como vindo de outras fontes, é pertinente aos relatórios, que se encontram na seção Anexos deste trabalho, e a referência para encontrar os trechos mencionados está devidamente feita.

Segue a relação dos documentos abaixo, com os títulos sob os quais cada um aparece nos Anexos, e que utilizaremos para referência do leitor quando formos citar as ações alocadas neles, citando também as páginas em que podem ser encontradas as atividades mencionadas. Apenas o relatório referente aos anos 1999 e 2000 não possui numeração de páginas:

- Relatório de Atividades - Gestão 1999-2000

- O trabalho da ABONG em 2001

- O trabalho da ABONG em 2002

- Democratizar a Democracia - ABONG Gestão 2001-2003

- Democratizar a Democracia - ABONG em 2003-2006 
Dadas breves explicações, passemos agora aos capítulos da análise propriamente dita, portanto. O primeiro deles foi inteiramente reservado às parcerias com atores de outros Estados ou globais firmadas pela ABONG, a atividade de cunho internacional que mais se destacou em nosso estudo. Por esse motivo, o capítulo a ela dedicado é um pouco mais longo do que os demais desta pesquisa. Em seguida, vem um capítulo dedicado aos outros tipos de ação com algum cunho internacional além das parcerias e articulações, e que trata também do peso da atuação internacional face à estritamente nacional. 


\section{Capítulo II}

\section{As parcerias e articulações da ABONG com atores internacionais e seus}

\section{objetivos}

Começaremos a nossa análise da ação de caráter internacional da Associação Brasileira de ONGs - baseada em relatórios da entidade que englobam período do ano de 1999, quando estes começam a ser disponibilizados na Internet, até o ano de 2003 tratando do tipo de atividade que observamos ser mais recorrente no que diz respeito à atuação da ABONG com algum cunho internacional. Estamos falando das parcerias, convênios, da articulação em redes ou outras ações similares em que a ABONG viu-se envolvida no período de análise, tenha a associação ocorrido com ONGs, redes de ONGs, ou outros atores.

Reunindo elementos lembrados por Korten (1990 apud Inoue, 1995), SchererWarren (1995 apud Inoue, 1995), Inoue (1995), Mance (2000) e Brodhead (1992), vamos, antes de passar às ações do tipo encontradas nos relatórios, elencar alguns principais motivos para a articulação de Organizações Não-Governamentais em redes. Eles ajudarão a nortear nosso olhar sobre as parcerias da ABONG, ainda que elas não sejam firmadas exclusivamente com outras entidades da sociedade civil. Seriam esses motivos 1) as ONGs do Norte e do Sul firmam parcerias em que as primeiras contribuem para o fortalecimento das segundas 2) parcerias são firmadas entre ONGs, ou redes de ONGs, com o intuito de estabelecer troca de informação, de experiência ou compartilhamento de recursos escassos 3) parcerias são firmadas com o objetivo de fazer face aos desafios globais que se apresentam às ONGs no complexo cenário internacional de hoje 4) parcerias são uma estratégia das entidades para passarem do nível micro para o macro, do local para o global 5) a articulação entre todos os movimentos resulta no fortalecimento de cada movimento em particular.

Pudemos detectar nas menções a parcerias feitas nos relatórios da ABONG foram 12 ao todo no período de análise - todos os motivos para buscar o engajamento em articulações descritos acima, em maior ou menor grau, a depender da modalidade do convênio ou parceria. Apenas, no caso das parcerias que não são Norte-Sul, não está presente, obviamente, o interesse do fortalecimento das entidades do Sul com o auxílio de entidades e órgãos do Norte. Houve, ainda, parcerias com entidades internacionais mas com foco mais local, às quais são menos aplicáveis os motivos de busca de 
projeção do nível local para o global e de necessidade de enfrentamento de desafios globais.

\section{1- Parcerias para fortalecimento institucional}

Consideramos como parcerias para fortalecimento institucional todas aquelas em que a ABONG firmou convênios ou se articulou de alguma forma com o intuito de aprimoramento técnico ou qualitativo, para si, associadas ou regionais. Os motivos para a Associação se engajar em parcerias aqui, portanto, teriam relação com o estilo de articulações Norte-Sul, com a finalidade de desenvolvimento das ONGs do Sul. Troca de experiências e recursos podem estar envolvidos, embora o cerne dessa modalidade de parceria seja mormente a transferência de recursos, conhecimento ou outros de uma parte mais fortalecida para a outra menos forte. Poderíamos dizer, ainda, da parte das ONGs do Sul, que os convênios com o Norte ajudam no enfrentamento de desafios globais ora existentes - por meio da melhor preparação para tal enfrentamento, auxílio financeiro, ou de outras formas - e podem ainda, da mesma forma, ajudar as ONGs do Sul a alçarem-se do nível micro ao macro, do local para o global.

Encontramos ao todo, nos relatórios da ABONG analisados, seis menções a parcerias ou articulações que a entidade integra ou integrou com contrapartes internacionais, visando o desenvolvimento, capacitação e fortalecimento institucional da Associação como rede e de suas associadas. Os itens encontrados foram uma parceria entre o Grupo de Estudos do Terceiro Setor (GETS), integrado pela ABONG e outras entidades brasileiras, a United Way-Canada Centraid (UW-CC), rede de organizações não-governamentais do Canadá, e os governos de ambos os países; o Programa de Articulação e Diálogo das Agências Ecumênicas Européias (PAD); o International Forum on Capacity Building (IFCB); o Programa de Desenvolvimento Institucional (PDI) da ABONG; um projeto de capacitação de ONGs para uso da Internet com apoio da Fundação Kellog; e, por fim, o assessoramento de voluntários da rede de ONGs suíça Unité à Associação Brasileira de ONGs. Todas, é importante notar, envolvem parceiros do Norte. Vamos explicar melhor, abaixo, do que se trata cada uma das articulações.

\section{- Articulação GETS, United-Way-Canada Centraid, e governos do Brasil e}

Canadá: Convênio envolvendo a rede GETS, representando as organizações nãogovernamentais do Brasil (formada pela ABONG e pelas ONGs Fala Preta; Fundação 
Projeto Travessia; Fundação SOS Mata Atlântica; Programa Voluntários do Conselho da Comunidade Solidária; e Centro de Voluntariado de São Paulo); a United WayCanada Centraid, representando as organizações não-governamentais canadenses (rede não-governamental de combate à pobreza do Canadá, com 122 unidades de assistência espalhadas por todo aquele país ${ }^{11}$ ); a Agência Canadense de Cooperação Internacional (CIDA), representando o governo canadense; e pela Agência Brasileira de Cooperação (ABC), representando o Ministério das Relações Exteriores do Brasil. A parceria foi firmada em 1997 com o objetivo de transferência de tecnologia entre os dois países. Foi executada por meio de oficinas acerca de captação de recursos. De acordo com a ABONG, o que era aprendido com sua participação no GETS era repassado às associadas. Os documentos Relatório de Atividades 1999-2000, O trabalho da ABONG em 2001 (p.11) e O trabalho da ABONG em 2002 (p.24) mencionam oficinas realizadas no âmbito do convênio em seus respectivos anos de abrangência. O relatório Democratizar a Democracia - ABONG 2001-2003 (p.25) dá conta do encerramento da parceria GETS, UW-CC e governos em 2003, com o lançamento das publicações Captação de Recursos - da Teoria à Prática, Facilitação de Oficinas - da Teoria à Prática e Modelo Colaborativo - experiência e aprendizados de desenvolvimento comunitário em Curitiba.

\section{- Processo de Articulação e Diálogo entre as Agências Ecumênicas}

Européias (PAD): O PAD é uma rede formada por agências ecumênicas européias Ajuda da Igreja Norueguesa, Serviço das Igrejas Evangélicas na Alemanha para o Desenvolvimento, Igrejas Protestantes da Suíça, entre outras - e por entidades ecumênicas, movimentos sociais e Organizações Não-Governamentais brasileiras dentre elas, a Associação Brasileira de $\mathrm{ONGs}^{12}$. Criado em 1995, o projeto tem dois eixos centrais de discussão e atuação: direitos humanos e desenvolvimento organizacional das entidades que o integram, por meio da troca de experiências. Apesar de um dos eixos declarados do PAD ser a questão dos direitos humanos, em seus relatórios a ABONG dá ênfase à faceta do programa de contribuição para o fortalecimento institucional das ONGs. Cita-o no documento Relatório de Atividades Gestão 1999-2000 a propósito da publicação, em 2000, de um Manual de Fundos Públicos e Privados no âmbito da parceria.

\footnotetext{
${ }^{11} C f$. www.unitedway.ca, acesso em 10 de janeiro de 2008.

${ }^{12} C f$. www.pad.org.br, acesso em 10 de janeiro de 2008.
} 
- International Fórum on Capacity Building (IFCB): O IFCB é integrado por representantes da União Européia, Programa das Nações Unidas para o Desenvolvimento (PNUD), Banco Mundial, Banco Interamericano de Desenvolvimento (BID), e, ainda, por ONGs, agências e fundações européias e norte-americanas. Tem como objetivo o fortalecimento institucional das ONGs do Sul. Segundo o relatório $O$ trabalho da ABONG em 2001 (p.11), a Associação faz parte da coordenação do IFCB na América Latina, junto com a Associación Latinoamericana de Organizaciones de Promoción (Alop), e a Fundación Promotora de Vivienda (Fuprovi), da Costa Rica. A coordenação tem o objetivo de cumprir a agenda do Fórum no continente. A ABONG cita, além de sua presença na coordenação do IFCB na América Latina, participação em dois grandes eventos ligados ao Fórum: Conferência Latino-Americana, em 2000, no Rio de Janeiro, e encontro mundial nos EUA, em maio de 2001. As entidades como União Européia, PNUD, Banco Mundial, entram com apoio e financiamento de iniciativas para fortalecimento institucional das ONGs do Sul. No âmbito de sua atuação na coordenação do IFCB e para cumprir a agenda do Fórum, a Associação Brasileira de ONGs cria, em 2001, um Programa de Desenvolvimento Institucional das ONGs Brasileiras, articulado ao seu próprio Programa de Desenvolvimento Institucional, criado no mesmo ano.

- Programa de Desenvolvimento Institucional da ABONG (PDI): No ano de 2001, a ABONG cria seu Programa de Desenvolvimento Institucional. Ele visa o desenvolvimento da entidade e das associadas por meio de oficinas para capacitação e encontros, e, de acordo com a Associação, é implementado de forma descentralizada, levando em conta as peculiaridades de cada Organização Não-Governamental. Essa descentralização é possível com a execução do programa por meio das Regionais da ABONG, orientadas pela coordenação nacional. De acordo com a ABONG, a experiência adquirida em articulações como o PAD e o convênio GETS-UW-CC é utilizada no PDI, sendo que este tem apoio e financiamento do IFCB e do Programa de Apoio ao Desenvolvimento Institucional e Sustentável (PADIS). O PADIS é um programa que subsidia iniciativas ligadas ao desenvolvimento e fortalecimento institucional de entidades não-governamentais e também de instâncias governamentais que atuem em parceria para o enfrentamento de problemas ambientais e na promoção do desenvolvimento sustentável. Ele é executado pelo Instituto Internacional de Educação 
do Brasil (IIEB) - entidade não-governamental brasileira que implementa projetos e capacita na área de meio ambiente - e financiado com recursos da Embaixada dos Países Baixos ${ }^{13}$. O PDI da ABONG é uma das 22 propostas apoiadas e financiadas pelo PADIS. A criação do PDI é citada no relatório O trabalho da ABONG em 2001 (p.10).

\section{- Articulação com a Fundação Kellog para implementação do programa} Informação e Comunicação na Era das Redes: Uso Estratégico da Internet: Em 2002, com a obtenção de apoio da Fundação W.K Kellogg - entidade filantrópica privada norte-americana, ligada à fabricante de cereais Kellogg - a ABONG e a Rede de Informações para o Terceiro Setor (RITS) elaboram e implementam o programa Informação e Comunicação na Era das Redes: Uso Estratégico da Internet. O objetivo do projeto foi a capacitação de ONGs associadas da ABONG da região Nordeste, nos anos de 2002 e 2003. Um dado interessante é que a W.K Kellog figura na página da ABONG na Internet como um apoiador permanente. As informações referentes à articulação com a Kellogg para capacitação de ONGs no uso da Internet estão em $O$ trabalho da ABONG em 2002 (p.31).

\section{- Articulação com a rede suíça Unité, que forneceu voluntários para} assessorar a ABONG: O relatório O trabalho da ABONG em 2001 (p.9), traz a informação de que, de 1999 a 2001, a ABONG contou com o apoio de voluntários da Unité - rede de voluntários suíços - na organização de atividades a nível nacional e regional. Não há no texto uma referência explícita à questão da transferência de conhecimento, ou de que se trate de uma ajuda com vistas ao desenvolvimento institucional, mas houve utilização do know how dos voluntários em atividades e ações da ABONG. Foram cedidos, após um evento da Unité em que houve participação da Associação, os voluntários Carlo Wallnöfer e Nadia Piemotesi.

Podemos notar, pela descrição de cada parceria acima e suas características, um interesse contínuo da Associação Brasileira de ONGs em estar envolvida em articulações de cooperação internacional para desenvolvimento institucional. Algumas articulações são antigas, caso do PAD, que data de 1995, e do convênio com a UW-CC, que durou de 1997 a 2003. Além disso, as parcerias articulam-se, encadeiam-se umas

\footnotetext{
${ }^{13} C f$ www.iieb.org.br, acesso em 10 de janeiro de 2008.
} 
nas outras - O IFCB tem relação com PDI, que, por sua vez, aproveita a experiência do PAD e da parceria com o Canadá para ser criado. Assim, elas têm toda uma dinâmica e aparentam estar na agenda diária da ABONG.

Vemos ainda que a ABONG se associa, na busca pelo fortalecimento institucional, não só a outras entidades não-governamentais como ela, aproveitando também iniciativas do Estado - caso do convênio com a United Way-Canada Centraid envolvendo governos canadense e brasileiro - e a organismos internacionais - caso do IFCB, que envolve PNUD, Banco Mundial, entre outros.

\section{2 - Parcerias ligadas a outras metas}

Neste grupo de parcerias ligadas a outras metas, consideraremos aquelas articulações envolvendo objetivos ligados a propósitos da entidade que não apenas o fortalecimento institucional por meio de capacitação técnica, aquisição de conhecimento, transferência de recursos ou de informação.

Se ouvirá falar aqui, algumas vezes, em fortalecimento da sociedade civil dentre os objetivos das parcerias e articulações citadas, e o fortalecimento da sociedade civil brasileira é uma das linhas-mestras dentre as metas da ABONG, não deixando de depender de melhor preparação técnica e profissionalização das entidades. Entretanto, o fortalecimento da sociedade civil vai bem além dessas questões - que podem ser encaradas como um de seus componentes - e tem relação com a democratização de espaços públicos, expansão de direitos, ampliação da cidadania e dos mecanismos de participação. Alcançando esses resultados, seria mais fácil e quase certo alcançar outras metas mais finalitárias que são plataformas por excelência de muitas ONGs, tais como justiça social, universalização da educação, desenvolvimento sustentável, garantia de direitos humanos e direitos das minorias, entre outros. Falaremos aqui de parcerias ligadas a ambas as coisas: as que têm metas que, em última instância, resultam no fortalecimento da sociedade civil, e também de articulações que estão ligadas à promoção direta de objetivos mais finalitários - justiça social, direitos das minorias, que também são parte integrante do ideário e princípios da ABONG.

Veremos aqui que, não se tratando já da questão da busca por maior capacitação e institucionalização, há uma ampliação do leque de parceiros da Associação Brasileira de ONGs, que já não fica restrito às entidades e atores do Norte. As ONGs e redes de ONGs do Sul aparecerão mais aqui. 
Estarão presentes como fatores estimuladores das parcerias de que trataremos aqui questões como a necessidade de troca de informações, experiência e compartilhamento de recursos escassos; a necessidade de enfrentamento dos desafios globais que se apresentam às ONGs; a possibilidade das ONGs de alçarem-se do nível micro para o macro, do local para o global; e a articulação entre muitos movimentos para fortalecimento de cada movimento em particular.

Seis articulações com seus focos fora daquele do fortalecimento institucional e profissionalização foram encontradas por nós na análise dos relatórios. Foram elas a Mesa de Articulação das Redes Nacionais de ONGs da América Latina e Caribe, que é um foro integrado por vários países do continente americano; o Fórum Social Mundial; a parceria entre ABONG e a rede de entidades não-governamentais francesa Coordination Solidarité, Urgence et Dévelopment (Coordination SUD); a articulação com a Transparency International para constituição de um escritório Transparência Brasil; a Plataforma Interamericana de Direitos Humanos, Democracia e Desenvolvimento (PIDHDD), que não é integrada, mas apenas apoiada por ela e tem participação de suas associadas; e a Marcha Mundial das Mulheres, também não integrada pela Associação e sim por filiadas, apenas apoiada pela ABONG.

Dividimos esses itens em dois subgrupos: parcerias e articulações com alguma relação com a questão do fortalecimento da sociedade civil, e parcerias e articulações com objetivos mais finalitários e menos ligados ao interesse de construção de uma sociedade civil mais forte, como questões de direitos humanos, direitos das minorias, problemas sociais, etc.

\section{1 - Parcerias que têm relação com a questão do fortalecimento da sociedade civil}

Três articulações integram este grupo ao todo, buscando, por meio do diálogo e da troca de experiências, a democratização de espaços públicos, ampliação da cidadania e de mecanismos participativos e outras metas passíveis de resultar, em última instância, no fortalecimento da sociedade civil. São elas a Mesa de Articulação de Redes e Associações Nacionais de ONGs da América Latina e Caribe, o Fórum Social Mundial e o convênio ABONG-Coordination SUD. Trataremos, abaixo, das características de cada uma delas. 
- Mesa de Articulação de Redes e Associações Nacionais de ONGs da América Latina e Caribe: A Mesa nasce em 2000, no âmbito da Conferência da América Latina do International Forum on Capacity Building, realizada no Rio de Janeiro naquele ano. É citada no relatório Democratizar a Democracia - ABONG em 2003-2006 (p.15), a propósito de atividades que desenvolveu nos anos de 2004, 2005 e 2006, que fogem ao escopo de nossa análise Segundo o documento, a articulação tem quatro eixos. São eles democracia e desenvolvimento, integração regional, defesa dos bens globais e, por fim, paradigmas ou referenciais políticos. A Mesa envolve 16 alianças, plataformas ou associações de Organizações Não-Governamentais da América Latina e Caribe, e 11 países da região. Segundo definição da ABONG, as entidades que a integram têm um trabalho "focado na participação cidadã nas políticas locais e regionais, no desenvolvimento das sociedades civis locais, na busca do desenvolvimento e no fortalecimento da democracia”14. A parceria é executada por meio de reuniões dos membros, diálogo, intercâmbio de informações e de experiências acerca das questões que compõem os quatro eixos acima mencionados.

- Fórum Social Mundial: O Fórum Social Mundial (FSM) é citado pela primeira vez nos relatórios da ABONG por ocasião da realização de sua primeira edição em 2001 e em razão da realização, ainda naquele ano, de eventos preparatórios para o FSM 2002. As menções aparecem no documento O trabalho da ABONG em 2001 (p.45). A Associação Brasileira de ONGs integrou o Comitê Organizador do Fórum Social Mundial enquanto as edições aconteceram no Brasil. A partir de 2004 ele passa a ocorrer em cidades de outros países e não mais em Porto Alegre, sua cidade-sede originária. Ineditamente em 2008, ocorreu em mais de uma cidade do mundo simultaneamente. Hoje, a constituição do Comitê Organizador depende de onde o FSM acontecerá, mas há um Escritório Coletivo permanentemente responsável pelo Fórum que fica em São Paulo, e que do qual a ABONG faz parte. É uma articulação profundamente ligada à promoção de objetivos que são caros à ABONG - ampliação da cidadania, democratização de espaços públicos, busca de um mundo alternativo àquele da globalização. O Fórum Social Mundial é definido como "um espaço de debate democrático de idéias, aprofundamento da reflexão, formulação de propostas, troca de experiências e articulação de movimentos sociais, redes (...) ele se propõe a facilitar a

\footnotetext{
${ }^{14}$ Cf. Parcerias Internacionais, Mesa de Articulação América Latina e Caribe, Apresentação, disponível em www.abong.org.br, acesso em 10 de janeiro de 2008.
} 
articulação, de forma descentralizada e em rede, de entidades e movimentos engajados em ações concretas, do nível local ao internacional, pela construção de um outro mundo ${ }^{15}$ ”. Além dessas questões, ressaltamos o fato também de o FSM ter nascido como um contraponto ao Fórum Econômico Mundial, realizado em Davos na mesma época. Há que se esclarecer aqui, também que por suas características de manter as entidades ligadas a ele em constante articulação, por gerar eventos preparatórios e paralelos ao longo de todo ano antes que ocorra a edição do Fórum em si, consideramos o FSM mais uma parceria e uma rede do que um simples evento, e que, por isso não o incluímos no capítulo seguinte deste trabalho, que tratará, entre outras coisas, da ação da ABONG via participação ou organização de eventos do tipo encontros para discussão e diálogo (seminários, congressos, debates). O FSM é classificado pela própria ABONG, em sua página na Internet, como uma parceria internacional ${ }^{16}$. Além de mencionado no documento $O$ trabalho da $A B O N G$ em 2001, o Fórum Social Mundial é citado em $O$ trabalho da ABONG em 2002 (p.11), a propósito da realização de eventos paralelos a ele (Fórum Temático Argentino, Fórum Social Europeu e Fórum Social Meditarrâneo, Fórum Social da Palestina), e, ainda, em Democratizar a Democracia - ABONG Gestão 2001-2003 (p.10), a propósito da participação da Associação Brasileira de ONGs no FSM de 2003.

- Parceria ABONG-Coordination SUD: Parceria da ABONG firmada justamente durante a edição de 2003 do Fórum Social. O acordo é mencionado no relatório Democratizar a Democracia - ABONG Gestão 2001-2003 (p.11). De acordo com o referido relatório, os objetivos do convênio seriam "permitir a ONGs brasileiras e francesas conhecer e partilhar experiências de desenvolvimento local, interagir com as políticas públicas e participar de debates no âmbito mundial, estabelecendo uma diplomacia não-governamental” (grifo nosso). O convênio é executado por meio de encontros, seminários, organização de publicações. Chamamos a atenção, especificamente, para um dos objetivos declarados da parceria, o de atingir uma diplomacia não-governamental. O trecho abaixo explicita o que a Associação Brasileira de ONGs entende por isso:

\footnotetext{
${ }^{15} C f$. www.forumsocialmundial.org.br, acesso em 26 de fevereiro de 2008.

${ }^{16} C f$. Parcerias internacionais, Fórum Social Mundial, disponível em www.abong.org.br, acesso em 10 de janeiro de 2008.
} 
“Atualmente, as ONGs não se satisfazem apenas com a intervenção a nível de ação local, 'concreta', querem estar presentes em outras instâncias (de organizações internacionais), além de suas próprias (fóruns sociais), para trabalhar com a questão dos direitos e responsabilidades, da governança mundial, do desenvolvimento sustentável, etc ${ }^{\text {17. }}$.

Vemos, então, que existe uma ambição por parte da ABONG no sentido de influir na atuação dos organismos internacionais, de fazer parte de um cenário de governança global, de participar da construção de normas e regras, de democratizar esses espaços, o que pode ser relacionado à questão do fortalecimento da sociedade civil.

\section{2 - Parcerias ligadas a objetivos finalitários}

Aqui, vamos tratar das parcerias e articulações internacionais ligadas a objetivos de caráter mais finalitário e imediatista do que o objetivo grande, difuso e a longo prazo de fortalecimento da sociedade civil. O número delas encontrado em nossa análise foi idêntico ao das parcerias que têm relação com o fortalecimento da sociedade civil: foram três ao todo. A diferença é que, até o momento, tivemos uma atuação direta da ABONG no que toca às parcerias e aqui, em duas das três articulações, ela apenas apóia associadas que são as firmadoras dos convênios e, em uma delas, vincula-se e depois se desvincula. Um indício de que questões como o fortalecimento da sociedade civil e o fortalecimento institucional são mais importantes para ela? Talvez.

As articulações agrupadas aqui são um entendimento com a Transparecy International para criação de um escritório Transparência Brasil, a Plataforma Interamericana de Direitos Humanos, Democracia e Desenvolvimento, e a Marcha Mundial das Mulheres. Seguem as características de cada uma:

\section{- Articulação com Transparency International para criar escritório} Transparência Brasil: Em 2000, segundo consta no Relatório de Atividades - Gestão 1999-2000, a Associação Brasileira de ONGs e outras entidades se articularam no sentido de criar a Transparência Brasil (TBrasil) - escritório da Transparency

\footnotetext{
${ }^{17}$ Cf. Parcerias Internacionais, Coordination SUD, disponível em www.abong.org.br, acesso em 10 de janeiro de 2008.
} 
International no Brasil. À época, a ABONG passa a fazer parte do Conselho Deliberativo do escritório assim que ele é fundado, juntamente com Sindicato da Indústria da Construção Civil de São Paulo (Sinduscon-SP); Pensamento Nacional das Bases Empresariais (PNBE); Associação Brasileira de Empresários pela Cidadania (Cives); União Nacional dos Analistas e Técnicos de Finanças e Controle e Instituto Ethos. Atualmente, embora não tenha mais representação no Conselho Deliberativo da TBrasil, a ABONG figura como membro-fundador da entidade, que é uma rede global de combate à corrupção ${ }^{18}$. Além de citar a implantação do escritório TBrasil, o relatório referente aos anos 1999 e 2000 fala da realização de campanha de conscientização sobre problemas sociais gerados pelo desvio de verbas públicas, campanha essa focada nas eleições municipais de 2000. A ABONG menciona a TBrasil também no relatório $O$ trabalho da ABONG em 2001 (p.6), a propósito da campanha Vigília Cívica contra a Corrupção, apoiada pelo escritório brasileiro e que teve participação da Associação Brasileira de ONGs, Ordem dos Advogados do Brasil (OAB), Confederação Nacional dos Bispos do Brasil (CNBB), Central Única do Trabalhador e outras entidades. Tratase, portanto, de uma iniciativa da ABONG em um certo momento da qual ela posteriormente desligou-se, com o intuito finalitário de combate à corrupção.

\section{- Plataforma Interamericana de Direitos Humanos, Democracia e}

Desenvolvimento: A PIDHDD é citada no relatório O trabalho da ABONG em 2002 (p.18), quando o documento faz referência ao fato de, em abril daquele ano, duas associadas da ABONG assumirem a gestão, para o período 2002-2005, de instâncias da PIDHDD no Brasil. São elas o Movimento Nacional de Direitos Humanos (MNDH), que assume a coordenação geral, e a Federação de Órgãos para Assistência Social e Educacional (Fase), que assume o colegiado brasileiro. O documento fala ainda da participação da Associação Brasileira de ONGs em um dos projetos da coordenação brasileira da PIDHDD: o programa Relatores Nacionais em Direitos Humanos, Econômicos, Sociais e Culturais, inspirado em modelo das Nações Unidas (programa Relatores Especiais Temáticos da ONU) e implementado com o apoio do Programa de Voluntários das Nações Unidas (UNV) e da Secretaria de Estado de Direitos Humanos do Brasil. Foram eleitos relatores nacionais em educação, saúde, trabalho, moradia, meio ambiente e educação no Brasil. Entre eles, na época, estava Sérgio Haddad,

\footnotetext{
${ }^{18}$ Cf. www.transparencia.org.br, acesso em 12de Janeiro de 2008.
} 
presidente da ABONG, escolhido para ser relator na área de educação. Desde então, houve outras eleições para composição do quadro de relatores e já não há alguém da Associação entre eles. Ainda segundo o relatório, as principais finalidades da Plataforma, integrada por organizações não-governamentais de vários países da América Latina, são “fortalecer a vinculação entre direitos humanos, democracia e desenvolvimento, além de incidir sobre as políticas públicas nacionais e em foros e espaços internacionais”. A coordenação brasileira da PIDHDD - para a qual foram eleitas as associadas da ABONG em 2002 - chama-se Plataforma Brasileira de Direitos Humanos, Econômicos, Sociais, Culturais e Ambientais (Plataforma DhESCA Brasil). Entre outras ações, ela fiscaliza a observância, no Brasil, do Pacto Internacional de Direitos Econômicos, Sociais e Culturais (PIDESC), firmado no âmbito das Nações Unidas em 1966 e, ainda, dos compromissos feitos em conferências mundiais como a de Meio Ambiente (Rio de Janeiro, 1992), Direitos Humanos (Viena, 1993), Desenvolvimento Social (Copenhagen, 1995) e da Mulher (Pequim, 1995) ${ }^{19}$. Os objetivos por parte da PIDHDD, portanto, são mormente finalitários. A ABONG não chegou nunca a vincular-se como uma das parceiras, e, em um dado momento, participou de um projeto. É uma situação diferente daquela do escritório da Transparência Brasil, com a Associação buscando a parceria de forma direta mas depois se distanciando dela.

- Marcha Mundial das Mulheres: A Marcha Mundial das Mulheres é mencionada no relatório O trabalho da ABONG em 2002 ( p.14). O documento diz da realização, em 17 de outubro daquele ano - Dia Internacional de Combate à Pobreza e à Violência Sexual - de diversas atividades ligadas à Marcha em estados brasileiros. O relatório fala ainda sobre as plataformas de luta da seção brasileira da rede Marcha Mundial, como aumento do salário mínimo e combate à violência doméstica, em especial no campo. No Brasil, aliás, especificamente para representar as mulheres do campo, foi criada a Marcha das Margaridas. A rede Marcha Mundial das Mulheres surgiu em março de 2000, após um período de articulação, envolvendo 6 mil organizações de 159 países e territórios. Envolve mobilizações, encontros, debates, a nível nacional e internacional. Seus objetivos são "a luta contra a pobreza e a violência sexista”. Os países onde possuem coordenações nacionais cuidam da organização

\footnotetext{
${ }^{19} C f$. www.dhescbrasil.org.br, acesso em 13 de janeiro de 2008.
} 
periódica de atividades e de problemas e reivindicações locais. Há também uma coordenação internacional, integrada por representantes de vários Estados, que trata das lutas globais da Marcha Mundial. Particularmente no Brasil, onde a Sempreviva Organização Feminista - associada da ABONG - é responsável pela Marcha, uma das bandeiras internacionais é a luta contra a Associação de Livre Comércio das Américas (Alca) ${ }^{20}$. Assim, vemos que a Marcha Mundial das Mulheres tem focos locais, regionais, globais. Constitui forma de troca de experiência entre as entidades a ela ligadas, de fortalecimento, de alcance de um nível além do nacional, de estratégia das ONGs para fazerem face aos desafios globais. A ABONG não esteve vinculada, no período de nossa análise, a nenhum projeto vinculado à Marcha nem nunca figurou como membro da rede mundial. Cita a ação ligada a ela, em um de seus relatórios, apenas como forma de declarar apoio e endossar as atividades da articulação.

\section{Encerrando: um breve balanço das parcerias}

Passaremos a seguir, no próximo capítulo, a outros tipos de atuação com algum cunho internacional da ABONG, além das parcerias e articulações. Antes, no entanto, faremos um pequeno balanço dos tipos de parceria encontrados. Foram, ao todo, seis convênios Norte-Sul mencionados, ligados ao objetivo de fortalecimento institucional. Foram também seis relacionados aos demais objetivos da ABONG que não esse, tendo três deles relação com a questão do fortalecimento da sociedade civil, e o mesmo número apresentando ligação com busca mais imediata de mudanças políticas e sociais - demos o nome, a essas mudanças buscadas, de objetivos finalitários.

No entanto, no que toca aos objetivos finalitários, a participação direta da Associação Brasileira de ONGs nas articulações foi mais escassa. No único caso em que encabeçou uma delas - negociações com a Transparency International para criação de um escritório da Transparência Brasil - houve um desligamento posterior. A Tabela 1, a seguir, ilustra os dados:

\section{Tabela 1}

\footnotetext{
${ }^{20} C f$. www.sof.org.br, acesso em 13 de jneiro de 2008.
} 


\begin{tabular}{|c|l|l|c|}
\hline \multicolumn{4}{|c|}{ Menções a parcerias } \\
\hline $\begin{array}{c}\text { Visando o desenvolvimento } \\
\text { institucional }\end{array}$ & \multicolumn{3}{|c|}{$\mathbf{6}$} \\
\hline $\begin{array}{c}\text { Visando os demais objetivos da } \\
\text { ABONG }\end{array}$ & $\begin{array}{l}\text { Fortalecimento } \\
\text { da sociedade } \\
\text { civil }\end{array}$ & $\begin{array}{l}\text { Participação } \\
\text { direta }\end{array}$ & 3 \\
\cline { 3 - 4 } & $\begin{array}{l}\text { Part. das } \\
\text { associadas }\end{array}$ & - \\
\cline { 2 - 4 } & $\begin{array}{l}\text { Objetivos } \\
\text { finalitários }\end{array}$ & $\begin{array}{l}\text { Participação } \\
\text { direta }\end{array}$ & 1 \\
\cline { 3 - 4 } & $\begin{array}{l}\text { Part.das } \\
\text { associadas }\end{array}$ & 2 \\
\hline Total & $\mathbf{6}$ \\
\hline
\end{tabular}

Percebemos, portanto, que o fortalecimento institucional e o objetivo maior de um fortalecimento da sociedade civil são marcadamente importantes para a ABONG. Ela trabalha para prover fortalecimento institucional a si e a suas associadas, e também dialoga a nível internacional para democratizar espaços públicos, criar livres foros de diálogo entre entidades não-governamentais e, assim, fortalecer a sociedade civil.

Vimos ainda que ela não dialoga, em suas parcerias e articulações, apenas com outras entidades não-governamentais a ela semelhantes. Há eventual abertura ao Estado, a organismos internacionais, que apareceu mais recorrentemente no caso das parcerias para fortalecimento institucional. Entretanto, o diálogo com outras ONGs e redes de ONGs se dá de forma mais freqüente.

O tipo de ação da Associação Brasileira de ONGs de que estamos tratando neste capítulo - parcerias e articulações - foi a forma de atuação que apareceu o maior número de vezes em nossa análise. Nenhuma outra ação de cunho internacional foi tão recorrente, como veremos no capítulo que virá a seguir.

Além disso, um aspecto que chama a atenção nelas é que, na grande maioria das parcerias e articulações mencionadas nos relatórios da ABONG de 1999 a 2003, há o envolvimento direto da entidade, e não apenas apoio a associadas suas diretamente envolvidas. Dentre as 12 articulações ou parcerias citadas, em apenas dois casos - o da PIDHDD e o referente à Marcha Mundial das Mulheres - a ABONG não é uma das firmadoras do convênio. Levantamos alguns motivos para essa importância, e desenvolveremos melhor nossa argumentação acerca de parcerias e articulações no espaço reservado às conclusões deste trabalho. 


\section{Capítulo III}

\section{As outras formas de ação de caráter internacional da ABONG e o peso da ação internacional face à nacional}

Dedicamos este capítulo de nosso trabalho à análise de todas as demais formas de ação de caráter internacional da ABONG além das parcerias e articulações, que foram as encontradas mais recorrentemente nos relatórios por nós estudados, como foi possível constatar no capítulo anterior.

Também vamos tratar, aqui, do peso de toda a atuação com algum cunho internacional da Associação Brasileira de Organizações Não-Governamentais, face àquelas ações de cunho estritamente nacional. A forma mais clara por nós encontrada para dar uma noção da importância de um tipo de ação frente ao outro foi uma comparação numérica, muito embora devamos reiterar o que já foi dito antes: não se trata de um quadro estatístico exato, e sim de uma aproximação da realidade, em razão das opções que fizemos para operacionalizar nossa análise dos relatórios da ABONG.

Dividimos aquelas menções a ações de cunho internacional da Associação Brasileira de ONGs que não dizem respeito a parcerias, convênios e articulações em três grupos ao todo. Além das parcerias, há basicamente, portanto, mais três formas de atuação, aconteça tal atuação diretamente por parte da ABONG ou por meio de acompanhamento indireto, tratando-se de ações de suas associadas - obviamente, quando a ação parte diretamente da Associação, podemos considerar que a sua efetivação tem maior importância para esta e, portanto, que essa forma específica de interação com o cenário ou com atores internacionais tem mais força do que aquelas nas quais não há um envolvimento primário da entidade.

Pois bem: os três grupos por nós criados para agrupar aqueles tipos de ação diferentes das parcerias e articulações foram 1) a organização ou participação da ABONG em eventos do tipo encontro para discussão e diálogo (tais como seminários, debates, congressos, conferências) 2) o acompanhamento e posicionamento acerca de temas da agenda internacional ou com alguma relação com o cenário internacional e 3) monitoramento do cumprimento de tratados internacionais no Brasil, denúncia de descumprimento dos mesmos ou de violação de direitos e coleta de informações locais para divulgação internacional.

Acompanharemos, na análise das ações encaixadas em cada um desses três agrupamentos, se houve envolvimento direto da ABONG ou não nas atividades, e qual 
dessas formas de atuação foi a mais freqüente após as parcerias. Depois, faremos um breve balanço delas para, a seguir, enfim, encerrar fazendo a comparação das ações de cunho internacional face ao número daquelas estritamente nacionais. Como o nosso foco neste trabalho é, principalmente, ter uma idéia sobre como se dá a atuação internacional da ABONG, não haverá um detalhamento e análise comentada das ações estritamente nacionais. Uma síntese de quais foram elas está disponível na seção Anexos deste trabalho.

\section{1 - A organização ou participação da ABONG em eventos do tipo encontro para discussão e diálogo.}

A organização ou participação em seminários, congressos e outros eventos cujo foco é o debate constituiu uma parte não-desprezível das atividades com algum cunho internacional da Associação Brasileira de Organizações Não-Governamentais ao longo de nosso período de análise. Aqui, reunimos os itens do tipo encontrados nos relatórios da ABONG.

Vale lembrar que não entram, neste capítulo, as edições do Fórum Social Mundial, porque o consideramos como possuindo mais características de parceria do que de um simples evento. Também não entrarão aqui os eventos, debates, seminários e oficinas realizados no âmbito do FSM, durante cada uma das edições que entram em nosso período de análise, porque consideramos o Fórum um item único. E isso porque são em número muito grande os debates, seminários e outros eventos pequenos e grandes que ocorrem em seu âmbito, e não são todos eles que aparecem mencionados nos relatórios da Associação Brasileira de ONGs. Também não entra nesta seção do trabalho a igualmente já mencionada Marcha Mundial das Mulheres, que consideramos também como uma rede, não ficando sua ação restrita aos eventos periódicos a ela ligados.

Procuramos agrupar aqui, como já dito, eventos com intenção de discussão e diálogo e de caráter mais pontual do que as redes e parcerias aos quais a ABONG esteve ligada em nosso período de análise, mas, ainda assim, eventos que nem sempre são tão pontuais e isolados assim, pois muitos têm alguma espécie de desdobramento, ou um canal de diálogo sempre aberto entre os participantes, o que faz com que tenham um pouco das características de parcerias ou redes. Pudemos constatar que eles são uma boa parte da parcela de ações da ABONG com algum cunho internacional: foram 10 
encontrados no período de análise, ao todo. Portanto, eles vêem logo atrás das parcerias e articulações no que diz respeito à quantidade de menções. Consideramos aqui, no caso, os eventos voltados para temas além-fronteiras e, também, os que tiveram participação de algum parceiro internacional.

No tipo de atividade que agruparemos nesta seção, em que predomina a discussão e o diálogo entre os participantes, as Organizações Não-Governamentais podem trocar experiências e conhecimentos - algo que vimos que interessa a elas constantemente fazer, analisando as parcerias em que a ABONG se envolveu em nosso período de estudo. A troca de experiência e conhecimentos entre ONGs ou delas com outros atores, pudemos constatar, é um viés importante das parcerias e articulações. Assim, poderíamos dizer que a reunião das Organizações Não-Governamentais, constantemente, em seminários e debates - às vezes de forma isolada, sem desdobramentos, e outras não - é uma edição reduzida e, às vezes, um ponto de partida para sua reunião em parcerias? Talvez sim.

Cabe lembrar que, se muitos encontros com esse foco de discussão e troca de experiência são eventos isolados, uma porção deles, como dissemos, não tem um caráter tão pontual. Eles podem gerar, e geram, desdobramentos e compromissos - dentre eles o próprio nascimento de parcerias, ou o estabelecimento de agendas, por exemplo. Os seminários, debates, também podem ser ações resultantes de parcerias e articulações, uma das formas de execução e realização das mesmas - veremos aqui seminários realizados no âmbito da parceria ABONG-Coordination SUD, por exemplo. Dito isso, passemos, então, à descrição dos eventos, que será mais sucinta do que a exposição que fizemos acerca das redes, articulações e parcerias.

A primeira menção a uma ação do tipo aparece no Relatório de Atividades Gestão 1999-2000. O documento faz referência ao fato de ter sido a ABONG a única organização da sociedade civil brasileira a participar da Conferência Mundial de Educação, realizada em Dakar, a convite, segundo o documento, da Organização das Nações Unidas para a Educação, a Ciência e a Cultura (Unesco).

Além de ter participado da conferência, diz ainda o relatório, esteve presente também a fórum paralelo que reuniu ONGs de países diversos e que defendeu a destinação de 6\% do PIB de cada Estado para a educação - proposta que acabou nãoincluída no documento final do encontro oficial. Vemos que, ao participar do fórum paralelo, a ABONG manteve um canal para diálogo e troca de informações com as outras ONGs, entidades como ela. Ela se articulou com as demais ONGs - uma 
articulação para o momento, que pode ter tipo um desdobramento ou outro, o relatório nada menciona - e acompanhou as discussões dos Estados no encontro "oficial”, como o chamou.

Prosseguindo com a análise, no ano seguinte ao da Conferência Mundial de Dakar, em 2001 (O trabalho da ABONG em 2001, p.9) a Associação Brasileira de ONGs apóia e participa do I Colóquio Internacional de Direitos Humanos de São Paulo, organizado pelo Consórcio Universitário pelos Direitos Humanos. Este é formado pela Pontifícia Universidade Católica de São Paulo (PUC-SP), Universidade de São Paulo (USP) e Columbia University. O objetivo do evento, que, de acordo com a ABONG, passa a ser realizado anualmente após a primeira edição, é a "formação e aperfeiçoamento de jovens profissionais e militantes engajados no trabalho de redução das violações aos direitos humanos e injustiças sociais”. A Associação Brasileira de ONGs coordena uma das oficinas do colóquio, sobre sociedade civil. Apesar do registro da ABONG de que a iniciativa, de 2001 para a frente, passou a ser anual, o Colóquio Internacional só é mencionado nos relatórios como tendo ocorrido mais uma vez, em $O$ trabalho da ABONG em 2002 (p.17). O evento não é citado nos relatórios que dizem respeito a 2003. Tem as características por nós mencionadas, de troca de experiências, informações. É organizado por um consórcio além-fronteiras de universidades, o que significa uma troca de experiências também além das fronteiras internacionais, com a participação da Columbia University. O fato de ser organizado por um consórcio mostra ainda que o Colóquio é uma atividade no âmbito de uma parceria.

Seguindo em frente com a descrição dos eventos para discussão e diálogo em que a ABONG se envolveu, ainda no ano de 2001, a Associação Brasileira de Organizações Não-Governamentais participa do $4^{\circ}$ Encontro Brasil de Unité, e do seminário Filantropia, Responsabilidade Social e Cidadania, promovido pela Fundação Kellogg, já mencionada neste trabalho, assim como a rede de voluntariado suíça Unité. Ambos os itens são citados no documento O trabalho da ABONG em 2001 (p.9). É no âmbito deste $4^{a}$ Encontro da Unité que a Associação acorda com a rede suíça a cessão de dois voluntários seus para assessoramento, assunto sobre o qual tratamos já no capítulo referente às parcerias e articulações. Portanto, um desdobramento resulta do encontro para discussão. A Kellogg também é nossa conhecida do capítulo anterior apóia um programa de capacitação de ONGs no uso da Internet - e já mencionamos também o fato de ela figurar na página da Associação na web como um de seus apoiadores permanentes. 
Continuando com a descrição dos eventos, em 2001 também, em São Paulo, a Associação Brasileira de ONGs organiza, em parceria com a Associación Latinoamericana de Organizaciones de Promoción e com a PUC-SP, o seminário Estudos sobre as Organizações Não-Governamentais na América Latina: Situação e Perspectivas. A ação é citada em O trabalho da ABONG em 2001 (Ibid). A Alop é uma rede em diálogo constante com a ABONG - está envolvida com o FSM também, por exemplo, e está com a Associação Brasileira de ONGs na coordenação da América Latina do International Forum on Capacity Building., o IFCB. O evento que citamos, organizado por ambas, constitui um momento adicional de estreitamento de relações, troca de informações, pontos de vista, constatações, em um diálogo constantemente aberto com um direcionamento que interessa a ambas: a cooperação internacional entre as ONGs, notadamente das da América Latina, no que diz respeito à Alop.

Falaremos agora da participação da Associação Brasileira de ONGs na Feira e Congresso Internacional de Cidades - Urbis. Trata-se de evento cuja primeira edição aconteceu em 2001, mas que só é mencionado nos relatórios da ABONG a partir de 2002. Naquele ano e em 2003, a Associação monta estande na Feira ( $O$ trabalho da ABONG em 2002, p.36, Democratizar a Democracia - ABONG Gestão 2001-2003, p.11). Realizada até a sua terceira edição, em 2004, a Urbis foi um projeto que teve o apoio do governo brasileiro e organismos internacionais, com o intuito de troca de experiências e discussão de soluções urbanas para diversos problemas de metrópoles e cidades. Foi mais um evento no qual a ABONG pôde estar em contato com temas e entidades de seu interesse, intercambiar informações. Vale lembrar, inclusive, que a Associação Brasileira de ONGs foi uma das entidades governamentais que batalharam pelo Estatuto das Cidades e contribuiu para sua elaboração. Em O trabalho da ABONG em 2001 (p.7), a Associação comemora a sanção pelo Poder Executivo, em julho daquele ano, do projeto de lei que deu origem ao Estatuto.

A ABONG demonstra interesse ainda com relação à problemática urbana quando, em 2003, além de ter participado da Feira e Congresso Internacional das Cidades, organiza um evento paralelo à Urbis, sobre o mesmo assunto. Estamos falando do seminário Pelo Direito à Cidade, que a ABONG realizou no âmbito da então recémfirmada parceria com a rede francesa de ONGs Coordination SUD. Foram discutidos temas como ocupações urbanas e participação cidadã na gestão de cidades durante o evento. Naquele mesmo ano, também a título de atividades ligadas ao convênio com a Coordination SUD, foram realizados também seminários com os temas Diplomacia e 
Solidariedade Internacional: como os atores não-governamentais podem pesar nos debates e nas negociações internacionais, e Comércio Ético e Solidário. Os três encontros são citados no documento Democratizar a Democracia - Gestão ABONG 2001-2003 (p.12). Assim, temos mais uma vez eventos para discussão, troca de informações e diálogo sendo realizados no âmbito de uma parceria.

\section{2 - Acompanhamento e posicionamento com relação a temas da agenda internacional ou ligados ao cenário global}

Falaremos, aqui, sobre as vezes em que, no período de análise, foi detectada a preocupação da Associação Brasileira de ONGs em monitorar acontecimentos do cenário internacional e, eventualmente, se posicionar com relação a eles. Dos acontecimentos e agenda inseridos no complexo cenário de governança global, o que preocupou a ABONG no período de 1999 a 2003, nosso intervalo de análise? A entidade tomou alguma atitude, tentou exercer alguma pressão, dirigiu-se ao Estado ou as instâncias regulatórias internacionais? É o que veremos agora. Foram nove ações do tipo, ao todo.

A primeira delas encontrada ocorre em 1999, sendo mencionada no documento Relatório de Atividades - Gestão 1999-2000. Em abril daquele ano, a Associação Brasileira de ONGs dá o seu apoio à realização de um Tribunal da Dívida Externa, organizado pela Cáritas Brasileira (organismo da Confederação Nacional dos Bispos do Brasil), pela Central de Movimentos Populares (CMP), pelo Conselho Nacional de Igrejas Cristãs (Conic) e pela Coordenadoria Ecumênica de Serviço (Cese). O Tribunal foi parte da campanha Jubileu 2000, do Conselho Mundial de Igrejas, a favor do perdão da dívida dos países pobres. O “veredicto" a partir da reunião das entidades participantes, no Rio de Janeiro, foi pelo não-pagamento da dívida ${ }^{21}$. A partir dele, é realizado, naquele mesmo ano, em setembro, um Plebiscito da Dívida Externa, com a participação de 5 milhões de pessoas, segundo a ABONG. Os participantes, desta vez de várias unidades da Federação, votaram sobre o pagamento ou não da dívida, e pela manutenção ou não de acordo então em vigência com o Fundo Monetário Internacional (FMI). As opções vencedoras foram o não-pagamento da dívida externa e a nãomanutenção do acordo com o FMI.

\footnotetext{
${ }^{21} C f$. www.jubileubrasil.org.br, acesso em 17 de Janeiro de 2008.
} 
Assim, vemos a Associação Brasileira de ONGs atenta a uma questão ligada à política internacional, a saber, a questão da dívida externa, e ligada a uma campanha pelo não-pagamento que insta pelo perdão do débito para países pobres e menos ricos em geral. Por certo o que preocupa mais a ABONG é a questão da dívida no Brasil, mas o apoio ao Tribunal e ao Plebiscito, a ligação com a campanha Jubileu 2000 - que é também contra a Alca, um outro posicionamento que coincide com o da Associação Brasileira de ONGs - mostra um acompanhamento de movimentos do cenário internacional relativos à economia, e uma tomada de posição formal com relação a eles.

Uma outra ação da ABONG que demonstra um acompanhamento daquilo que se passa no âmbito da governança global, e mais uma vez um posicionamento contrário ao pagamento da dívida externa, é o fato de, ainda em 1999, segundo o documento Relatório de Atividades - Gestão 1999-2000, a Associação ter pedido a abertura de inquérito junto à Procuradoria Geral da República (PGR) para garantir que recursos obtidos por meio de empréstimo do Banco Mundial - US\$ 252 milhões - fossem utilizados no combate à pobreza. Segundo diz a Associação Brasileira de ONGs no relatório em questão, a Presidência da República havia enviado pedido ao Congresso para utilização do montante no pagamento da dívida externa. Nem neste relatório, nem nos posteriores em nosso período de análise, a ABONG fala do resultado do pedido de abertura de inquérito, movido por ela em parceria com outras entidades, junto à Procuradoria Federal dos Direitos do Cidadão da PGR. Desta vez, no entanto, temos não só um acompanhamento e uma tomada de posição, mas, ainda, uma atitude, a saber, a recorrência a uma instância judicial com o fim de atingir um objetivo.

A próxima ação de que falaremos aqui ocorre no ano de 2001, em setembro, durante o evento de lançamento da segunda edição do Fórum Social Mundial, que aconteceria no ano seguinte. Por ocasião dos atentados de 11 de setembro, a ABONG e outras ONGs presentes divulgam um manifesto de solidariedade irrestrita aos Estados Unidos. O fato é mencionado pela entidade no relatório O trabalho da ABONG em 2001 (p.5). Além da condenação aos atentados, entretanto, o manifesto traz uma ressalva acerca do perigo de “atos de retaliação, terrorismo e vingança contra outros povos”.

Trata-se, aqui, de um posicionamento acerca de algo remoto para a ABONG, que pouca ligação tem com os interesses práticos da entidade, mas ainda assim mostra que há uma percepção e um envolvimento com o global, uma atenção aos possíveis desdobramentos de um acontecimento que afinal, pela sua magnitude, poderia trazer conseqüências maiores ou menores para todos os Estados, em aspectos os mais diversos 
- econômicos, sociais, relativos à segurança. Podemos dizer, então, que foi uma tomada de posição simbólica, mas ainda assim uma demonstração de predisposição ao acompanhamento e de que há um sentimento por parte da ABONG de que ela é também parte desse cenário global.

Ainda no ano de 2001, temos uma atividade do Fórum de ONGs-AIDS de São Paulo e Fórum de ONGs-AIDS do Rio de Janeiro, ambos integrados por associadas da ABONG. No âmbito da Campanha Internacional para Acesso aos Medicamentos Essenciais, organizada pela ONG global Médicos sem Fronteiras, os dois fóruns se mobilizam contra processo aberto na Organização Mundial do Comércio (OMC) para análise de leis de patentes em vários países, inclusive Brasil. De acordo com a ABONG, a pressão exercida pelas ONGs brasileiras resultou na "conquista do apoio da ONU ao programa brasileiro de combate à AIDS” (O trabalho da ABONG em 2001, p.7). Portanto, trata-se de um acompanhamento e de uma ação mais concreta com relação a uma situação global, com envolvimento das associadas da Associação Brasileira de ONGs.

Passemos agora para o ano de 2002, quando a Associação apóia novamente a campanha Jubileu 2000, desta vez na realização de um plebiscito para questionar se o governo brasileiro deveria, ou não, assinar o tratado da Alca e continuar participação das negociações para constituição da área de livre comércio, e, ainda, se o Estado brasileiro deveria fazer, ou não, acordo com os Estados Unidos para uso da base de lançamento de Alcântara (O trabalho da ABONG em 2002, p.15). De acordo com informações da ABONG, 10 milhões de pessoas votaram, e a opção "não” venceu para as três perguntas.

Novamente, portanto, vemos acompanhamento e posicionamento acerca do que se passa no cenário global no que toca ao âmbito econômico, sem ações mais concretas para influir no processo decisório. Temos, ainda, um acompanhamento das negociações e um posicionamento quanto à cessão da base de Alcântara.

Citando uma outra ação de 2002, em março daquele ano a Associação Brasileira de ONGs apóia uma mobilização iniciada pelo Movimento Nacional de Direitos Humanos - o mesmo de que já tratamos anteriormente, que integra a PIDHDD - com o objetivo de pressionar o Congresso Nacional para ratificação do Tratado de Roma, que estabeleceu a criação do Tribunal Penal Internacional Permanente, com a função de julgar casos de violação de violação contra os direitos humanos. A ABONG, aqui, mostra uma atuação indireta no lobby pela ratificação de um tratado internacional por 
parte do Brasil - apóia o MNDH, não sendo ela a idealizadora da campanha, a principal defensora da aprovação do Tratado de Roma. O apoio da ABONG à mobilização pela ratificação do Tratado é citado em dois momentos nos relatórios de nosso período de análise: em O trabalho da ABONG em 2002 (p.17) e em Democratizar a Democracia ABONG Gestão 2001-2003 (p.23).

Por fim, citaremos três ações mais, ambas no ano de 2003, que evidenciam uma preocupação e um acompanhamento, por parte da ABONG, de coisas que se passam no cenário internacional e suas implicações. A Associação relata que, durante a terceira edição do Fórum Social Mundial, naquele ano, em Porto Alegre, divulgou posicionamento contra a invasão do Iraque pelos Estados Unidos e Reino Unido, junto com outras ONGs. A segunda ação, ligada ao mesmo assunto, é o fato de que a ABONG integrou o comitê São Paulo contra a Guerra, movimento lançado pelas entidades não-governamentais daquele estado contra o conflito. A primeira ação citada, de divulgar posicionamento contra a guerra do Iraque durante o FSM 2003, guarda semelhanças com a de 2001, quando a ABONG divulga sua posição com relação aos atentados de 11 de setembro durante um evento preparatório para o FSM de 2002. As informações sobre esse posicionamento da ABONG com relação à guerra do Iraque estão no relatório Democratizar a Democracia -ABONG Gestão 2001-2003 (p.20). No documento, a entidade diz ter defendido, “em todas as ocasiões (...) uma saída diplomática e o respeito às resoluções da ONU”.

Também em 2003, a Associação Brasileira de ONGs declara em relatório que continua a divulgar uma posição contrária à constituição da Alca e, segundo ela, também à da cessão da base de Alcântara aos Estados Unidos. Em janeiro de 2003, no II Fórum Social Pan Amazônico, do qual a ABONG foi uma das organizadoras, o tema foi “Toda a América contra a Alca” (Democratizar a Democracia -ABONG Gestão 20012003, Ibid). Como a informação sobre a continuação da divulgação de uma posição contrária à Alca e à cessão da base é bastante vaga - não há detalhes sobre de que forma continuou tal divulgação - consideramos como item apenas a organização do Fórum Social Pan Amazônico.

3 - O monitoramento do cumprimento de tratados internacionais, denúncia de descumprimento dos mesmos ou de violação de direitos, e a coleta de informações locais para divulgação internacional 
A ABONG não tem uma ação muito destacada com relação a essas formas específicas de atuação, na qual muitas Organizações Não-Governamentais se especializam, a saber, monitoramento e fiscalização do cumprimento de tratados e reunião de dados para encaminhamento a nível global, destacadamente no que diz respeito a indicadores sociais e direitos humanos. Durante todo o período de análise, em apenas duas ocasiões houve menção a ações ligadas a atividades do tipo.

A primeira das menções aparece no Relatório de Atividades - Gestão 19992000. É citado o lançamento da $4^{\text {a }}$ edição, em 2000, do relatório Observatório da Cidadania. Os Observatórios da Cidadania são informes, com dados sobre desenvolvimento e situação sócio-econômica em geral dos Estados e foco especial na questão da seguridade social, por meio dos quais a Organização Não-Governamental global Social Watch monitora a situação dessas questões em cada um dos países em que tem representação ${ }^{22}$.

A ABONG, ela mesma, não faz parte do grupo de referência da rede Social Watch no Brasil. Entretanto, algumas de suas associadas integram tal grupo. A coordenação brasileira é composta pelo Centro de Estudos de Segurança e Cidadania da Universidade Cândido Mendes (Cesec-Ucam), Federação de Órgãos para Assistência Social e Educacional (Fase), Instituto de Estudos Sócio-Econômicos (Inesc), Centro Feminino de Estudos e Assessoria (Cfemea), Instituto Brasileiro de Análises Sociais e Econômicas (Ibase) e Criola. Dentre essas organizações, as associadas da ABONG são Fase, Inesc, Ibase, Cfemea e Criola. A Associação Brasileira de ONGs, além disso, não integra a coordenação ou grupo de referência da Social Watch no Brasil, mas está entre as entidades que a rede considera como secundariamente participantes da representação ${ }^{23}$.

Portanto, a ABONG apóia a iniciativa dos Observatórios da Cidadania, que, segundo o Relatório de Atividades - Gestão 1999-2000, além de desenvolver os relatórios sobre indicadores sociais, tem como mais um objetivo monitorar e divulgar a implementação dos acordos estabelecidos durante a Cúpula Mundial para o Desenvolvimento, em Copenhague, em 1995, e durante a Cúpula Mundial sobre as Mulheres, em Pequim, no mesmo ano.

\footnotetext{
${ }^{22} C f$. www.socialwatch.org/en/informeImpreso/Brasil, acesso em 17 de janeiro de 2008.

${ }^{23} \mathrm{Cf}$. http://www.socialwatch.org/en/acercaDe/organizacionesParticipantes, acesso em 17 de janeiro de 2008.
} 
Vamos agora tratar de um momento em que há constatação de violação de direitos humanos e realização de denúncia junto às instâncias internacionais regulatórias com participação da ABONG - o único momento do tipo ao longo de todo o nosso período de análise. Em 2001 (O trabalho da ABONG em 2001, p.17), o Fórum de Entidades pela Reforma Agrária da região sudeste, que a Associação Brasileira de ONGs integra juntamente com outras entidades, solicitou visita da Comissão de Direitos Humanos da Câmara dos Deputados às cidades de Altamira e Marabá, no Pará, a fim de verificar de perto a questão da violência no campo. O Ministério da Justiça e a Procuradoria Federal dos Direitos dos Cidadãos acompanharam a visita, bem como a ABONG e outras entidades. Familiares de líderes locais assassinados foram ouvidos. Depoimentos e informações sobre o assunto - incluindo partes de dossiês preparados pelas entidades - foram encaminhados à Presidência da República, ao então ministro da Justiça José Gregori, ao então ministro do Desenvolvimento Agrário Raul Jungmann e, ainda, à Corte Interamericana de Justiça, à ONU, e à Organização dos Estados Americanos (OEA).

Como já dito, trata-se da primeira vez, durante todo o período de análise, em que a ABONG fala de uma iniciativa que resultou em denúncia a instâncias internacionais de um caso de violação de direitos humanos.

Isso mostra que não há uma familiaridade da ABONG com a prática, e que as formas de ação que delimitamos neste grupo - monitoramento, compilação e encaminhamento de informações, denúncias - não são a principal maneira de atuação internacional da ABONG. No caso da confecção de relatórios para a Social Watch, ela não faz parte da coordenação brasileira, principal responsável pelos mesmos. No caso da denúncia sobre a violência no campo no Pará, é a única do tipo, e, mesmo assim, com a entrada em cena primeiro de instâncias governamentais nacionais. Depois, em conjunto com as ONGs, tais instâncias fazem com que o caso chegue ao âmbito internacional.

\section{Breve balanço das outras formas de atuação de caráter internacional, em comparação com as parcerias}

Pudemos constatar que os encontros para discussão, debate e troca de experiências, a exemplo do que ocorre com as ações do tipo parceria, são outra das formas preferenciais da ABONG de contato com o cenário e atores internacionais. 
Encontramos 10 menções a atividades do tipo em nosso período de análise. A quantidade chega próxima do número de parcerias mencionadas no mesmo período.

Se tivéssemos incluído dentre os encontros, debates, congressos e afins que compilamos também aqueles com participação da Associação ocorridos no âmbito das três edições do Fórum Social Mundial que entram em nosso período de análise, teríamos uma quantidade ainda maior desse tipo de ação, que em muitas aspectos se aproxima das parcerias, da articulação, da formação de redes. Não o fizemos porque não foram mencionados todos os eventos durante o FSM que foram organizados ou contaram com alguma participação da ABONG nos relatórios. Incluímos, é verdade, seminários ocorridos no âmbito da parceria ABONG-Coordination SUD, mas foram, de fato apenas três eventos do tipo no total ligados à parceria no período, e, diferentemente do que se aplica aos eventos que acontecem durante o FSM, tais seminários não ocorreram no âmbito de um evento maior da parceria. Basta, portanto, que consideremos o Fórum Social Mundial um grande evento único, com características fortes de parceria e rede.

Não é surpresa constatar que encontros para debate, discussão e troca de experiências se mostraram, em nossa análise das ações com algum cunho internacional da ABONG, quase tão recorrentes quanto as parcerias, redes e articulações. Afinal, os dois tipos de atuação têm vários aspectos em comum, como já vimos, e são próximos em muitos sentidos - troca de experiências, eventualmente estabelecimento de agendas, e, enfim, podemos dizer que objetivos que cercam encontros para diálogo e debate muitas vezes se assemelham muito aos que cercam as articulações e parcerias formais e estruturadas. A própria fusão de características de parceria e de evento para discussão e diálogo que há no Fórum Social Mundial, por exemplo, nos leva a perceber o quanto as duas espécies de ação podem ser próximas.

Vejamos: elencamos entre os possíveis objetivos das ONGs para estabelecer parcerias o intuito de estabelecer troca de informação e experiência, o que já vemos que ocorre no âmbito dos eventos para discussão. Um outro motivo possível levantado foi a necessidade das ONGs de se articularem para compartilhamento de recursos escassos, o que também pode acontecer no âmbito de um seminário ou congresso. Em um evento do tipo, uma entidade com recursos humanos ou materiais escassos para desenvolver determinado projeto pode receber informações sobre projeto pronto, semelhante, de uma outra entidade, e, ainda, fazer acordo para o uso de recursos humanos dessa entidade em oficinas para formação de multiplicadores, ou eventos semelhantes. Se levarmos em 
conta que o projeto hipotético pode ter relação com a necessidade de desenvolvimento e profissionalização de uma ONG, temos aí o objetivo do fortalecimento institucional também contemplado no âmbito de um evento com as características de seminários e afins. E, por fim, falamos ainda, no que diz respeito às parcerias e articulações, dos objetivos de passar do nível local ao global, fazer face a desafios globais do mundo contemporâneo e, ainda, fortalecer cada entidade em particular por meio da reunião de todas. Esses três objetivos também podem ser atingidos no âmbito de eventos para discussão, embora não de forma tão completa quanto o seriam em redes e articulações a longo prazo.

Por fim, prosseguindo com nosso balanço, encontramos menções a acompanhamento e posicionamento sobre questões da agenda internacional em número quase tão elevado quanto o das parcerias e os eventos para discussão e diálogo - 12 parcerias e articulações mencionadas, 10 eventos para diálogo, 9 menções a acompanhamento e tomada de posição.

No entanto, esse acompanhamento ou posicionamento é circunstancial e não sistemático - na maioria das vezes em que apareceu, os temas da agenda pelos quais a ABONG se interessou foram questões passíveis de influir de forma direta na realidade nacional. Nas duas vezes em que o acompanhamento não teve relação com temas assim - divulgação de declarações da ABONG acerca dos atentados de 11 de setembro e da II Guerra do Golfo, além de participação em campanha contra a intervenção no Iraque tratava-se de temas que tiveram repercussão global e geraram declarações e posicionamentos por parte de diversos atores e Estados. O impacto que trouxeram a nível mundial foi grande, e não é de espantar que a Associação tenha posicionado-se a respeito com declarações formais em conjunto com outras ONGs e, posteriormente, envolvido-se em campanha contra a intervenção no Iraque organizada por entidades de São Paulo.

Entretanto, permanece o fato de que a maioria dos acompanhamentos se deu quando havia um assunto passível de influenciar diretamente a realidade nacional em pauta. Essa atitude de um acompanhamento circunstancial, incidental - cujos resultados, no mais das vezes, não foram além da divulgação formal de uma posição, ou da mobilização, ou do apoio à mobilização da opinião pública - difere daquela aplicada às parcerias e aos encontros para discussão e diálogo, que guardam semelhanças com as parcerias. A Associação Brasileira de ONGs se organiza de forma mais sistêmica no que toca às parcerias e eventos para diálogo, é perceptível o interesse da entidade em manter 
abertos canais de diálogos e perceptíveis uma continuidade e periodicidade no que toca a essas ações. Em apenas um único momento, nos casos de acompanhamento acerca do que se passa no âmbito internacional, há uma tentativa por parte da Associação de influir diretamente no processo decisório acerca de um tema: trata-se de quando a ABONG, juntamente com outras organizações, pede a abertura de inquérito junto à Procuradoria Geral da República (PGR) para garantir que recursos obtidos por meio de empréstimo do Banco Mundial - US\$ 252 milhões - fossem utilizados pelo Estado brasileiro em ações de combate à pobreza. Há um outro caso de tentativa de influir na tomada de decisões, quando uma associada faz lobby junto ao Congresso pela ratificação de um tratado - MNDH se mobiliza pelo Tratado de Roma - mas neste caso não há participação direta da ABONG.

Um outro ponto a ser destacado é este: há ocasiões em que a ABONG se restringe ao apoio a entidades terceiras, sem atuar diretamente nos casos de acompanhamento da agenda e de temas de foro internacional. Ela apóia ações da campanha Jubileu 2000, da campanha do Fórum ONGs-AIDs de São Paulo contra o processo da OMC questionando o tratamento das patentes de remédios no Brasil, e há, ainda, o apoio ao próprio MNDH. Declarações de apoio sugerem que a Associação endossa as ações e tem consciência da importância delas, mas não são, necessariamente, o foco de sua ação com algum cunho internacional.

Verificamos a atuação direta da ABONG nos casos de acompanhamento da agenda e temas internacionais nos casos do fórum contra a Alca por ela organizado no Amazonas; da ação movida junto à PGR para questionar o uso de recursos do Banco Mundial pelo governo; da divulgação de posicionamentos, durante eventos, sobre os atentados de 11 de setembro e a invasão do Iraque em 2003; e da campanha referente à II Guerra do Golfo organizada por ONGs de São Paulo, de cujo comitê a ABONG diz ter participado - cinco itens de nove, a maioria, portanto. Entretanto, no que toca às parcerias e organização de eventos para discussão e debate, a Associação se envolve diretamente de forma mais freqüente, preocupa-se em fazer avançar essas ações e dar a elas continuidade. Apenas para recordarmos, no caso das parcerias 12 parcerias mencionadas no capítulo anterior, que foi dedicado a elas, houve apenas duas ocasiões em que não aconteceu o envolvimento direto da Associação Brasileira de ONGs como a firmadora dos convênios. No caso dos eventos para discussão e debate, em todas as 10 menções por nós encontradas a ABONG esteve envolvida diretamente, como participante ou organizadora. 
Vamos, por fim, ao balanço das ações da última categoria de menções a atividades com algum cunho internacional deste capítulo - monitoramento do cumprimento de tratados, realização de denúncias e divulgação de informações locais a nível internacional. O número de menções a ações dessa última espécie foi o mais reduzido encontrado em nossa análise - duas atuações do tipo somente, uma delas sem a participação direta da ABONG. A entidade cita em um dos relatórios o fornecimento de dados sócio-econômicos do Brasil por parte de associadas suas à rede global nãogovernamental Social Watch, mas não tem participação nesse fornecimento, apoiando, apenas, o trabalho realizado. Portanto, dentre as formas de ação da ABONG não está a compilação de dados sócio-econômicos, ou de violação de direitos, ou de qualquer espécie com o intuito de divulgá-los a nível internacional, a fim de que possam, talvez, embasar políticas e ações - por parte de ONGs, ou de organismos internacionais. Já no caso da denúncia da violação de direitos humanos no Pará, ligada à questão da violência no campo, foi a primeira vez nos relatórios por nós analisados que se mencionou ação da ABONG - em parceria com outras entidades, e em conjunto com instâncias governamentais brasileiras, vale lembrar - a resultar no encaminhamento de dados a instâncias internacionais regulatórias, o que leva a crer que não há familiaridade com a prática nem regularidade nela. Essa espécie de atuação, portanto - encaminhamento de denúncias, compilação de informações - também não constitui o foco das ações com algum caráter internacional empreendidas pela ABONG.

A Tabela 2, abaixo, ilustra as ações com algum cunho internacional por nós vistas neste capítulo, e relaciona-as com a quantidade total de menções a parcerias. Também é possível ter, analisando-a, uma noção de em que espécie de atividades a Associação Brasileira de ONGs envolveu-se ela mesma com mais freqüência - não apenas acompanhou ou declarou apoio - e constatar que a entidade tem uma participação direta em suas ações com algum cunho internacional com muito mais freqüência do que tem uma participação indireta.

\section{Tabela 2}

\begin{tabular}{|l|c|c|c|}
\hline \multicolumn{4}{|c|}{ Ações com cunho internacional - 1999 a 2003} \\
\hline $\begin{array}{l}\text { Forma de participação } \\
\text { da ABONG }\end{array}$ & Direta & Indireta & Total \\
\hline Parcerias & 10 & 2 & 12 \\
\hline
\end{tabular}




\begin{tabular}{|l|c|c|c|}
\hline Eventos para discussão & 10 & - & $\mathbf{1 0}$ \\
\hline $\begin{array}{l}\text { Acompanhamento da } \\
\text { agenda e do cenário }\end{array}$ & 5 & 4 & $\mathbf{9}$ \\
\hline $\begin{array}{l}\text { Monitoramento, } \\
\text { divulgação de } \\
\text { informações, denúncias }\end{array}$ & 1 & 1 & $\mathbf{2}$ \\
\hline & $\mathbf{2 6}$ & $\mathbf{7}$ & $\mathbf{3 3}$ \\
\hline
\end{tabular}

\section{4 - O peso das ações de caráter internacional face à ação nacional}

Com o fim de encerrar este capítulo, cabe fazer a comparação da quantidade de ações estritamente nacionais da ABONG no período de análise, face às ações com algum cunho internacional. Não discorreremos aqui, detalhadamente, sobre as formas de ação nacional da Associação, uma vez que nos interessa, para este trabalho, apenas a análise qualitativa daquelas ações com algum cunho internacional. A síntese das atividades nacionais em que a Associação Brasileira de ONGs se viu envolvida entre 1999 e 2003 está disponível, como já dissemos, na seção Anexos deste trabalho, com as devidas páginas de referência para que sejam encontradas nos relatórios, disponíveis na mesma seção. Para ter uma idéia do teor das atividades estritamente nacionais da ABONG, sugerimos consultar a síntese.

O que faremos aqui será dar um balanço numérico delas, das ações nacionais, face àquelas de caráter internacional. Contabilizando as atividades de cunho internacional do capítulo anterior e as do presente capítulo, temos ao todo 33 a ações do tipo em que a Associação Brasileira de ONGs envolveu-se direta ou indiretamente entre 1999 e 2003. Já as ações de cunho estritamente nacional no período foram em número bem maior. Com a divisão dos textos dos cinco relatórios em itens e excluindo dessa contabilização as ações presentes na seção Trabalho das Regionais, existente em dois dos documentos, separamos nada menos do que 76 itens - um número superior $230 \%$ ao de ações com algum cunho internacional.

Assim como as ações de cunho internacional, as ações estritamente nacionais abrangem uma variedade enorme de temas - e isso é explicável, já que a ABONG é a rede representante das Organizações Não-Governamentais brasileiras e se proclama defensora de várias plataformas. Envolve-se, portanto, em ações ligadas a todas essas plataformas. 
O fato de as ações estritamente nacionais serem significativamente em maior número do que aquelas com algum cunho internacional não surpreende em absoluto, uma vez que já expusemos, neste trabalho, o fato de não ser a Associação Brasileira de ONGs uma entidade de atuação global ou internacional e de não pretender sê-lo, ao menos por enquanto. O que interessa saber aqui, mormente, é se a relação da ABONG com o cenário, temas, atores internacionais é significativa e se pesa na balança do total das atividades nas quais a entidade se envolve. A conclusão é que sim, elas pesam, são em número quantidade bastante razoável, apesar de marcadamente menor do que a de ações de cunho estritamente nacional.

Essa constatação, aliada ao fato de que a Associação envolve-se diretamente nas ações com algum cunho internacional, com muito mais freqüência do que declara apoio, endossa ou acompanha ações de associadas ou de entidades terceiras - a proporção foi de 26 envolvimentos diretos para 7 indiretos - mostra que a cena internacional, as opções e movimentações que ela apresenta, estão longe de serem desimportantes para a ABONG. 


\section{Conclusões}

A ABONG tem uma preocupação em não restringir sua atuação ao âmbito nacional, possui um volume significativo de ações com algum cunho internacional, e aquelas nas quais mais investe e com as quais se envolve pessoalmente com mais freqüência dizem respeito à articulação e estabelecimento de parcerias com outros atores - primordialmente entidades não-governamentais semelhantes a ela - e à manutenção de canais de diálogo abertos a fim de promover troca de experiências, conhecimentos e, muitas vezes, celebração de novas parcerias. Os eventos do tipo encontro para discussão, vimos, podem ser uma das formas de manter tais canais abertos. Eles guardam semelhanças com as articulações e redes e foram as segundas atividades encontradas de forma mais recorrente em nossa análise dos relatórios da Associação Brasileira de ONGs, que englobou período de cinco anos.

Ambos, as parcerias e os eventos do tipo encontro para discussão e diálogo, serão o foco deste espaço destinado às conclusões de nosso trabalho, por constituírem o cerne da atuação com algum cunho internacional da ABONG.

Em nosso capítulo de análise das parcerias, falamos de antemão de algumas razões que geralmente levam as Organizações Não-Governamentais a se unirem em articulações e convênios - razões essas levantadas por Korten (apud Inoue, 1995), Inoue (1995), Mance (2000) e Brodhead (1992). Eram elas, a saber, o interesse no fortalecimento das entidades do Sul quando dos convênios Norte-Sul; o intuito de troca de informações, experiências ou compartilhamento de recursos escassos quando dos convênios entre ONGs em geral; o interesse das ONGs de fazer face, em conjunto, aos novos desafios surgidos no âmbito de uma sociedade global; e o fortalecimento de cada movimento em particular pela união de todos em rede. Quando falamos dos eventos para discussão e diálogo, no capítulo seguinte ao destinado às parcerias, apontamos algumas semelhanças e objetivos comuns a ambos os tipos de ação.

O que significa, entretanto, dizer que a articulação e a abertura de espaços para diálogo são as principais formas de ação com algum cunho internacional da Associação Brasileira de ONGs? Primeiramente, trata-se de uma reiteração da tendência atual à organização das Organizações Não-Governamentais em redes e à busca de cooperação umas com as outras. A ABONG, já por si uma rede, busca estabelecer contatos, conexões e diálogos, e a essa busca podem ser associados motivos, objetivos, razões 
que já ligamos aos agrupamentos de parcerias por nós criados a partir da análise dos relatórios, e que mencionamos também aqui, neste espaço dedicado às conclusões de nosso trabalho. De acordo com Afonso (1992), as Organizações Não-Governamentais vivem "o momento das redes", um momento em que "a crescente complexidade das crises sociais e das políticas internacionais (das quais cada vez menos escapam as crises nacionais) exigem um grande impulso para um intenso diálogo entre essas organizações, através de meios os mais rápidos e eficientes possíveis”.

Mas, mais do que dizer que o fato de a Associação buscar cooperação e articulação corrobora uma tendência do mundo globalizado e complexo referente às ONGs, mais do que dizer que ela atua dessa maneira buscando uma série de objetivos que autores já elencaram para tratar de Organizações Não-Governamentais no geral, podemos dizer ainda outra coisa - que as formas de atuação com algum cunho internacional às quais a ABONG dá preferência estão profundamente ligadas à própria razão de existência da entidade e a este pequenino fato já mencionado - a Associação já nasceu uma rede. Ela nasceu uma rede com o intuito de representar algumas entidades e enfrentar desafios complexos de um mundo novo, como já vimos. E essa representação implica em alguns focos específicos. Segue, abaixo, o que nos diz Lisandra Arantes Carvalho, a advogada e coordenadora do escritório da Associação Brasileira de ONGs em Brasília, sobre algumas diretrizes-mestras que norteiam a entidade:

“A ABONG nasceu sob a ótica do reconhecimento de direitos, com o fim de democratizar os espaços públicos, fortalecer movimentos sociais como um todo, atuar junto. Representa um campo de associadas, e a ABONG acaba representando as ONGs no campo internacional”.

Essa definição sobre as razões de existir da Associação Brasileira de ONGs, já mais ou menos delineada no capítulo em que falamos sobre as características da ABONG e aqui sintetizada pela coordenadora do escritório da entidade em Brasília, é o nosso elemento a conectar as parcerias, articulações, diálogos, trocas de experiência às finalidades bastante primordiais da ABONG. Uma ONG e uma representante de ONGs, a entidade encontra na criação de fóruns e espaços em que os movimentos e entidades se articulam e onde a junção de todos fortalece cada um, o ambiente perfeito para perseguir seus essas metas de democratizar espaços públicos, fortalecer movimentos sociais - metas essas que, vimos, acabam resultando no objetivo maior de 
fortalecimento da sociedade civil. Vimos que esse fortalecimento - no âmbito do qual estão inseridos capacitação técnica, desenvolvimento institucional - é marcadamente importante para a Associação por estar presente justamente nas parcerias e articulações nas quais a ABONG envolve-se diretamente. Os objetivos mais finalitários, de mudança mais a curto prazo, não recebem a mesma atenção.

O que concluímos aqui é que é natural que, para atingir objetivos tão caros a ela, a Associação se volte para instrumentos presentes hoje na cena internacional que facilitam bastante o alcance desses interesses - fronteiras tênues; a emergência de uma sociedade civil global e de um cenário de governança complexa com espaço para novos atores; a inserção de temas que fazem parte do universo das ONGs na agenda global a partir do período pós-Guerra Fria; a tendência geral de entidades não-governamentais como ela de se agruparem em rede pelo mundo todo por aquelas razões todas que já levantamos, e que incidem sobre a ABONG também - cooperação Norte-Sul, troca de experiências, compartilhamento de recursos escassos, entre outras.

Podemos citar, para ilustrar a forma de atuação da Associação Brasileira de ONGs, Brodhead (1992:119-120), que fala da tendência ao surgimento de uma nova qualidade de Organizações Não-Governamentais a partir do cenário de complexidade desenhado dos anos 1990 em diante:

"Historicamente, as ONGs contribuíram para o desenvolvimento internacional prestando serviços que visam ao bem-estar (particularmente educação e saúde) e assistência em caso de calamidades. Muitas ainda se mantêm voltadas para estes dois objetivos, mas alguns analistas notaram uma mudança na direção de um enfoque de desenvolvimento que enfatiza a sustentabilidade, a participação popular e a autoconfiança, o fortalecimento das potencialidades das instituições locais e a importância do conhecimento e tradição culturais nativos para a solução dos problemas locais”.

A Associação Brasileira de ONGs não é uma entidade de atuação internacional ou que se volte, de alguma forma, para contribuir com o desenvolvimento a nível global, como já vimos reiteradamente aqui. Mas pode com certeza ser encaixada nessa visão de mais foco no desenvolvimento, na participação, no fortalecimento das potencialidades de instituições locais em lugar da assistência - que poderíamos, talvez, relacionar àquilo que chamamos de objetivos finalitários neste trabalho. A cena e os atores internacionais são utilizados, pela ABONG, de forma a prover fortalecimento da 
ação nas bases - por meio de Associadas e regionais - e como meio de fortalecer a si mesma como rede à frente delas e à própria sociedade civil como um todo, de maneira a poder prosseguir com esse trabalho.

Taciana Gouveia ${ }^{24}$, integrante da Diretoria Executiva da Associação Brasileira de ONGs, indicada pela entidade para responder a nossas questões sobre a atuação de caráter internacional da mesma, fez considerações que corroboram nossas conclusões tiradas com base na análise documental e em princípios e objetivos declarados da ABONG. De acordo com ela, “o sentido da atuação nacional e internacional é promover a democracia, em um sentido político e de igualdade social. No campo internacional, nos aliamos a sujeitos que possam ajudar na busca desses objetivos”.

Taciana Gouveia destacou como as parcerias hoje mais importantes para a ABONG hoje o Fórum Social Mundial e a articulação com a rede francesa Coordination SUD. A primeira foi descrita por ela como "o maior fórum de fortalecimento da sociedade civil e relacionamento internacional da ABONG”. Já a segunda, de acordo com ela, "vai na linha do fortalecimento de plataformas internacionais como sujeitos políticos da diplomacia não-governamental”.

Por fim, a integrante da Diretoria Executiva confirmou um dado encontrado por nós na análise dos relatórios: o de que a Associação Brasileira de ONGs, em sua linha de ação, liga-se pouco à atuação mais imediatista, visando obter resultados de curto prazo. Ela está muito mais voltada para a questão da promoção do diálogo e da democratização de espaços. “A gente não atua fortemente aí, é um tipo de ação mais de pressão mesmo, essa de monitorar cumprimento de tratados, de fazer denúncia. E isso vale para a ação nacional e internacional”.

Concluímos a tarefa a que nos propusemos de traçar um quadro da ação de caráter internacional da ABONG, então, chegando a conclusões que podem ser sintetizadas em duas linhas principais. Primeiro, a entidade se lança além das fronteiras nacionais e estabelece contatos diversos com atores a fim de atingir os objetivos ligados à razão mesmo de sua existência - democratização de espaços, fortalecimento da sociedade civil. Faz isso em razão de uma série de condições favoráveis: o fenômeno da globalização, a dissolução das barreiras entre Estados-nacionais, a existência de uma sociedade civil global, os espaços abertos para novos atores na cena internacional.

\footnotetext{
${ }^{24}$ Entrevista pessoal, concedida em 11 de março de 2008. Optamos por falar com Taciana Gouveia após a conclusão da análise dos relatórios, a fim de confrontar dados encontrados e conclusões extraídas com a avaliação oficial da Associação Brasileira de ONGs de sua ação de caráter internacional.
} 
Segundo, a ação de caráter internacional da ABONG segue a linha da nacional e busca tais objetivos - de abertura de espaços públicos, de democratização por meio do diálogo político - mais do que busca o que chamamos neste estudo de objetivos finalitários. Ou seja, a ABONG faz uso dos recursos disponíveis no cenário internacional mais para um fortalecimento de esferas de diálogo e das ONGs enquanto atores do que para promover ações assistenciais ou de pressão. 


\section{Referências Bibliográficas}

ALMEIDA, Wellington Lourenço de. A conferência de Viena (Junho-93), O Papel das Ongs e a Globalização dos Direitos Humanos. Dissertação de Mestrado, Brasília: UnB, Departamento de Relações Internacionais, dezembro de 1995.

BRODHEAD, Tim. Cooperação e Divergência sobre a Colaboração entre ONGs, Doadores de Ajuda e Governos do Terceiro Mundo in Desenvolvimento in Desenvolvimento, Cooperação Internacional e as ONGs $-1^{\circ}$ Encontro Internacional de ONGs e o Sistema de Agências das Nações Unidas. Rio de Janeiro: PNUD - Programa de Desenvolvimento das Nações Unidas e IBASE - Instituto Brasileiro de Análises Sociais e Econômicas, 1992 (pp. 119-133).

CARESIA, Gislaine. ONGs Internacionais: personalidade jurídica, autorização para funcionamento no Brasil e atuação no sistema nas Nações Unidas. Campos de Goytacazes, RJ: XVI Encontro Preparatório para o CONPEDI - Congresso Nacional de Pesquisa e Graduação em Direito, 2007 (pp.1092-1110). Disponível em http://conpedi.org/manaus/anais.php. Acesso em 10 de janeiro de 2008.

INOUE, Cristina Yumie Aoki. Globalização, Organizações Não-Governamentais $e$ Redes de Comunicação por Computador: um Estudo Exploratório. Dissertação de Mestrado, Brasília: UnB, Departamento de Relações Internacionais, dezembro de 1995.

MANCE, Euclides André. A revolução das redes: a colaboração solidária como uma alternativa pós-capitalista à globalização atual. Petrópolis, RJ: Editora Vozes, 2000.

OLIVEIRA, Miguel Darcy de. Cidadania e Globalização: a política externa brasileira e as ONGs. Brasília: Instituto Rio Branco; Fundação Alexandre Gusmão; Centro de Estudos Estratégicos, 1999.

PELLAES NETO, Hélio Michelini. O papel das organizações não-governamentais na proteção internacional aos direitos humanos. Teresina: Jus Navigandi, ano 8, n. 157. Disponível em: http://jus2.uol.com.br/doutrina/texto.asp?id4=4587. Acesso em 10 de agosto de 2007.

SARAIVA, André Luiz Lara Resende. Autonomia e Participação: ONGs e a Sociedade Civil. Dissertação de Mestrado, Brasília: UnB, Departamento de Ciência Política, 2003.

SMOUTS, Marie-Claude. A cooperação internacional: da coexistência à governança mundial in SMOUTS, Marie-Claude (Org.), As novas relações internacionais: práticas e teorias. Brasília: Editora Universidade de Brasília, 2004 (pp.129-156).

TAVARES, Ricardo Neiva. As Organizações Não-Governamentais nas Nações Unidas. Brasília: Instituto Rio Branco; Fundação Alexandre Gusmão; Centro de Estudos Estratégicos, 1999.

VILLA, Rafael Duarte. A construção de um sistema internacional policêntrico: atores estatais e não-estatais societais no pós-Guerra Fria. Revista Cena Internacional, ano 3, n.2, 2001. Disponível em: http://mundorama.net. Acesso em 06 de janeiro de 2008. 
WAPNER, Paul. Governance in Global Civil Society in YOUNG, Oran R. (Org.), Global Governance - Drawing Insights from the Environmental Experience. Londres: The MIT Press, 1997 (pp.65-84). 